\title{
QUEEN'S
UNIVERSITY
BELFAST
}

\section{Novel free fatty acid receptor 1 (GPR40) agonists based on 1,3,4- thiadiazole-2-carboxamide scaffold}

Krasavin, M., Lukin, A., Zhurilo, N., Kovalenko, A., Zahanich, I., Zozulya, S., Moore, D., \& Tikhonova, I. G. (2016). Novel free fatty acid receptor 1 (GPR40) agonists based on 1,3,4-thiadiazole-2-carboxamide scaffold. Bioorganic \& Medicinal Chemistry, 24(13), 2954-2963. https://doi.org/10.1016/j.bmc.2016.04.065

Published in:

Bioorganic \& Medicinal Chemistry

Document Version:

Peer reviewed version

Queen's University Belfast - Research Portal:

Link to publication record in Queen's University Belfast Research Portal

Publisher rights

(c) 2016 Elsevier Ltd. All rights reserved. This manuscript version is made available under the CC-BY-NC-ND 4.0 license

http://creativecommons.org/licenses/by-nc-nd/4.0/,which permits distribution and reproduction for non-commercial purposes, provided the author and source are cited.

\section{General rights}

Copyright for the publications made accessible via the Queen's University Belfast Research Portal is retained by the author(s) and / or other copyright owners and it is a condition of accessing these publications that users recognise and abide by the legal requirements associated with these rights.

Take down policy

The Research Portal is Queen's institutional repository that provides access to Queen's research output. Every effort has been made to ensure that content in the Research Portal does not infringe any person's rights, or applicable UK laws. If you discover content in the Research Portal that you believe breaches copyright or violates any law, please contact openaccess@qub.ac.uk. 


\section{Novel free fatty acid receptor 1 (GPR40) agonists based on 1,3,4-}

\section{thiadiazole-2-carboxamide scaffold}

Mikhail Krasavin,* Alexey Lukin, Nikolay Zhurilo, Alexey Kovalenko, Ihor Zahanich, Sergey Zozulya,

Daniel Moore, and Irina G. Tikhonova

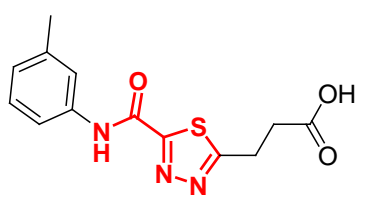

GPR40 $\mathrm{EC}_{50}=5.93 \mu \mathrm{M}$

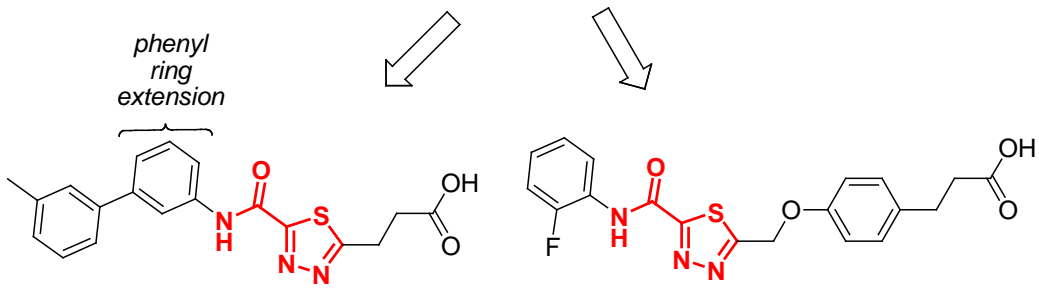

GPR40 $\mathrm{EC}_{50}=0.76 \mu \mathrm{M}$

GPR40 $\mathrm{EC}_{50}=0.56 \mu \mathrm{M}$

High plasma and metabolic stability Low plasma and metabolic stability

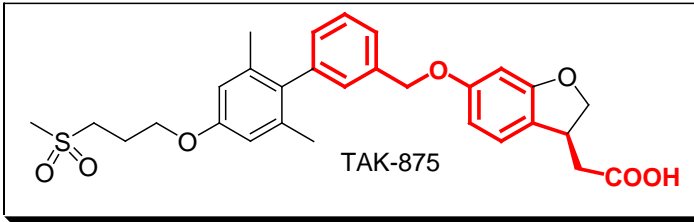




\section{Novel free fatty acid receptor 1 (GPR40)-agonists based on 1,3,4- thiadiazole-2-carboxamide scaffold}

Mikhail Krasavin, ${ }^{a,}{ }^{*}$ Alexey Lukin, ${ }^{b}$ Nikolay Zhurilo, ${ }^{b}$ Alexey Kovalenko, ${ }^{b}$ Ihor Zahanich, ${ }^{c}$ Sergey Zozulya, ${ }^{c, d}$ Daniel Moore, ${ }^{e}$ and Irina G. Tikhonova ${ }^{e}$

a Institutes of Chemistry and Translational Biomedicine, Saint Petersburg State University, Saint Petersburg, 199034 Russian Federation

b Lomonosov Institute of Fine Chemical Tehnologies, Moscow Technological University, 86 Vernadskogo Prospekt, Moscow, 117571 Russian Federation

${ }^{c}$ Enamine Ltd, 78 Chervonotkatska, Kyiv 02094, Ukraine

${ }^{d}$ Taras Shevchenko National University, 62 Volodymyrska, Kyiv 01033, Ukraine

${ }^{e}$ Molecular Therapeutics, School of Pharmacy, Medical Biology Centre, Queen's University Belfast, Belfast BT9 7BL, Northern Ireland, UK

* Corresponding author; phone: + 7931 3617872, fax: +7 8124286939.

E-mail address: m.krasavin@spbu.ru

\section{ABSTRACT}

Free fatty acid receptor 1 (FFA1), previously known as GPR40 is a G protein-coupled receptor and a new target for treatment of type 2 diabetes. Two series of FFA1/GPR4 4 agonists employing utilizing a 1,2,41,3,4-thiadiazole-2-caboxamide scaffold in their structure have been investigatedwere synthetized. Both series offered significant improvement of the potency compared to the earlier previously described 1,2,41,3,4-thiadiazole-based FFA1/GPR40 agonists and high selectivity for FFA1. Structural-Molecular docking predicts new aromatic interactions with the receptor that improve agonistenderstanding of the basis for such an improvement potency has been gained. The lead compoundsmost potent compounds from both series have beenwere profiled for their-in vitro ADME properties (plasma and metabolic stability, LogD, plasma protein binding, hERG binding and, CYP inhibition). One series suffered very rapid degradation in plasma and in presence of mouse liver microsomes.:- However, the other series delivered a lead compound that displayed an-excellenta reasonable ADME profile together with the improved FFA1 potency. zeross the panel of tests on top of the improved FFA1/GPR 40 agonist potency.

Keywords: 
GPR40, free fatty acid receptor 1, FFA1 agonists, bioisosteric replacement, total polar surface area, cLogP, metabolic stability, aqueous solubility.

\section{Introduction}

Agonists of free fatty acid receptor 1 (FFA1, also known as GPR40 prior to its de-orphanizationag in 2003) hold a particular promise have the potential to becomeare an attractive alternative to the currently used anti-diabetic agents, most of which lower glucose levels irrespective of the basal blood glucose eoncentration and can-cause hypoglycemia- ${ }^{1}$ FFA1 is highly expressed in the insulin-expressing beta cells of the pancreas and increases insulin secretion in a glucose-dependent manner, thus reducing risk of causing hypoglycemia. Under normal glycemiahomeostasis, FFA1 expression (primarily, in pancreatic islets of Langerhans) is low and increases only in hyperglycemic state. At higher expression levels, activation of the receptor by small molecule agonists triggers a signaling cascade that raises the levels of insulin, lowers the glucose levels and, consequently, downregulates FFA1 itself. ${ }^{2}$ Thus, the new therapeutic approach does not carry the danger of causing hypoglycemia (i. e. bringing the blood glucose concentration to dangerously low levels). Development of FFA1 agonists could provide therefore a new class of therapeutic agents This has led to an extensive research effort aimed at developing a class of agents-to treat type 2 diabetes mellitus-(T2DM). ${ }^{3}$ However, tFhe afea of FFA1agonist-based-theraputic targeting therapy-was adversely affected by the late-2013 discontinuation of phase III trial of Takeda's first-in-class agent fasiglifam (TAK-875). ${ }^{4}$ At the time of writing this manuscript, merely one clinical trial of an FFA1 agonist (Piramal's compound P11187 of the undisclosed structure) as conducted.5-The unexpected toxicity issues aside, the antidiabetic efficacy of TAK-875 was established in the course of Takeda's clinical investigation of the drugtrails, thereby providing the proof-of-principle for the entirely new therapeutic approach. ${ }^{6}$ At the time of writing this manuscript, merely one clinical trial of an FFA1 agonist (Piramal's compound P11187 of the undisclosed structure) has been conducted. ${ }^{5}$ ThereforeIt is expected that, the future quest for efficacious and safe FFA1 agonists should primarily focus on tackling their liver toxicity profile. ${ }^{7}$

The toxicity has been linked to the high lipophilicity of TAK-875 as well as most reported FFA1 agonists. ${ }^{7}$ An ifncrease ining the total-polar surface area (TPSA, $\AA^{2}$ ) -of FFA1 agonists could, in principle, provide a straightforar-solution to the problem. However, TAK-875 and many other advanced compounds of this class (such as Amgen's AMG-837, ${ }^{8}$ and Eli Lilly's LY2881835³) are based on the 3-[4-(benzyloxy)phenyl]propanoic acid core, which mimics the fatty acid endogenous ligands of the receptor (Figure 1). Hence, imparting too much polarity to a FFA1 agonist may simply render the ligand inactive.
Commented [IT1]: This is not true.

$$
\text { Commented [IT2]: Cannot understand the meaning of this part }
$$
of the sentence

Commented [I T3]: You don't use if afterwards. 
Figure 1. Advanced GPR40 agonists containing the 3-[4-(benzyloxy)phenyl]propanoic acid core.

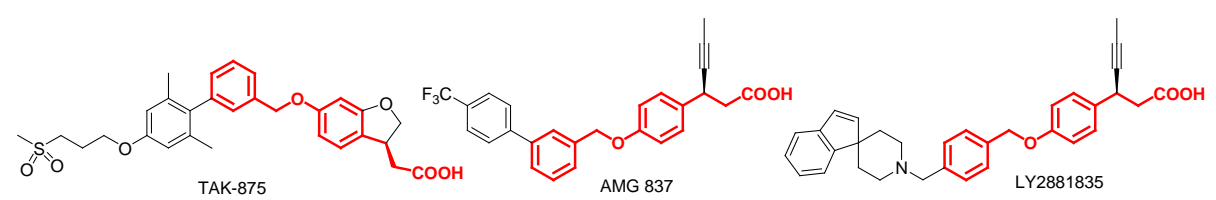

One effective approach to fine-tuning the lipophilicity profile of FFA1 agonists is to 'decorate' the 3phenylpropahoic acid scaffold with polar heterocyclic moieties. ${ }^{9}$ Alternatively, thise scaffold itselfcould be replaced with heterocyclic isosteres (as in Takeda's compounds $\mathbf{1}^{10}, \mathbf{2}^{11}$ and $\mathbf{3}^{12}$ as well as Amgen's indole-based compound $\mathbf{4}^{13}$ shown in Figure 2).

Recently, we have reported on the design and synthesis of a series of compounds containing the 3-(1,3,4thiadiazol-2-yl)propionic acid moiety (cLogP $=-0.09$ ) in lieu of the 3-phenylpropanoic acid moiety $(\mathrm{cLogP}=1.84) .{ }^{14}$ The best compound in the series (5) displayed moderate agonist potency against GPR40-FFA1 $\left(E_{50}=5.93 \mu \mathrm{M}\right)$ and an excellent in vitro ADMET profile (plasma protein binding, aqueous solubility and microsomal stability). The lower potency of $\mathbf{5}$ (compared, for example to TAK875, GPR40-EC $50=0.014 \mu \mathrm{M}^{15}$ ) can be rationalized by the overly polar character of the $1,2,41,3,4$ thiadiazole-2-carbozamide used in lieu of the (4-benzyloxy)phenyl moiety (vide supra). In this work, we investigated two compound series that stem from the initial series (represented by compound 5): i. 1,2,41,3,4-thiadiazole-2-carbozamides 6 designed to bring back the lipophilicity of the series (introduction of an additional phenyl ring results in a cLog $\mathrm{P}$ increase by two units ${ }^{16}$ ) and thus improve its potency; ii. 3-phenylpropanoic acids 7 containing the 1,2,41,3,4-thiadiazole-2-carbozamide periphery, designed with the same 'polar appendage' approach in mind as explored by us earlier ${ }^{9}$ (Figure 3).

Figure 2. Structures of heterocyclic analogs of 3-phenylpropanoic acid-based GPR40 agonists 1-4.

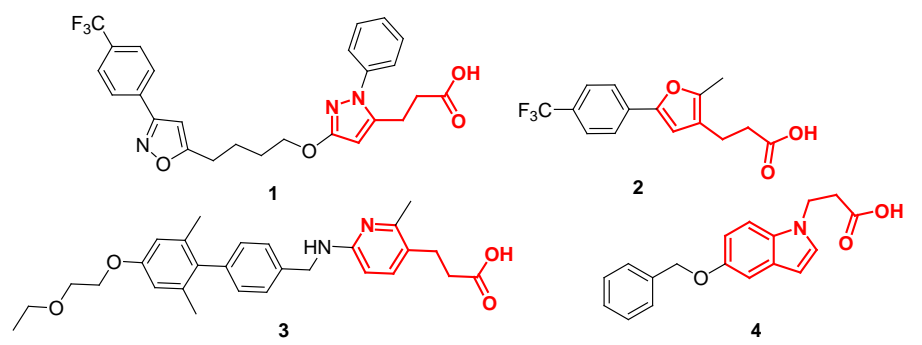

Figure 3 Two chemical series (6 and 7) explored in this work. 1,2,41,3,4-thiadiazole-2-carbozamide is highlighted. 


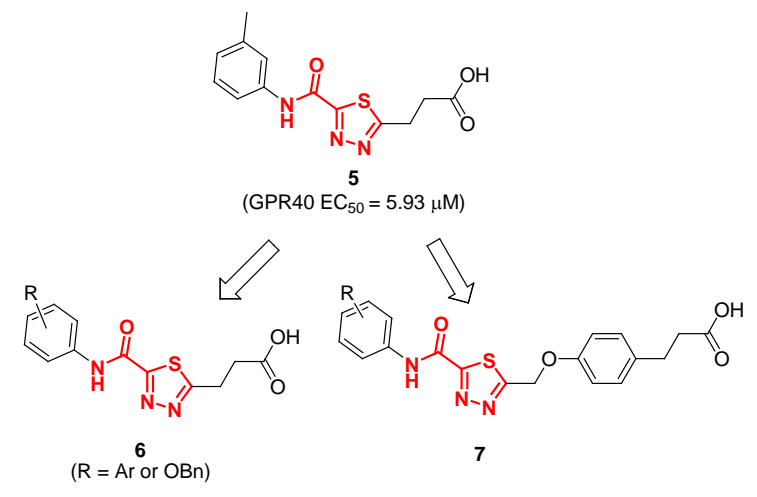

\section{Results and discussion}

Compounds 6a-e were synthesized from reported protocol. ${ }^{14,17}$ Treatment of $\mathbf{8}$ with elementary sulfur and morpholine (in the presence of $\mathrm{Et}_{3} \mathrm{~N}$ ) gave $\mathrm{N}$-aryl-2-moropholino-2-thiooxacetamides $\mathbf{9}$. The latter furnished hydrazino adducts $\mathbf{1 0}$ on reaction with hydrazine hydrate. Isolated by simple filtration and without further purification (see Experimental section), these adducts were transformed, in good to excellent yields, into target compounds 6a-e on reaction with succinic anhydride in glacial acetic acid (Scheme 1).

Scheme 1. Synthesis of 3-(1,2,41,3,4-thiadiazol-2-yl)propanoic acids 6a-e.<smiles>O=C(CCl)Nc1ccccc1</smiles>

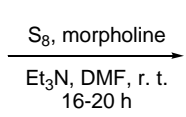<smiles>O=C(Nc1ccccc1)C(=S)N1CCOCC1</smiles>

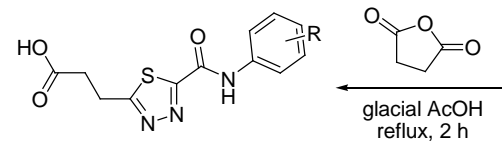

6a-e, $64-82 \%$ from 8

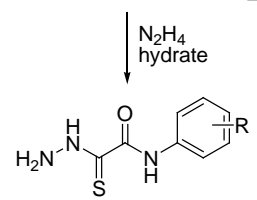

10

3-Phenylpropanoic acids 7a-I containing the 1,2,41,3,4-thiadiazole-2-carboxamide periphery were synthesized in a similar fashion from 2-chloroacetamides $\mathbf{1 1}$. The hydrazino adducts $\mathbf{1 2}$ were condensed (via CDI-promoted $N$-acylation and subsequent cyclodehydration on treatment with $\mathrm{HCl}$ ) with [4-(3tert-butoxy-3-oxopropyl)phenoxy]acetic acid (13) which, in turn, was obtained by alkylation of commercially available tert-butyl 3-(4-hydroxyphenyl)propionate (14) with ethyl bromoacetate and subsequent ester hydrolysis (Scheme 2).

Scheme 2. Synthesis of 3-phenylpropanoic acids 7a-1. 


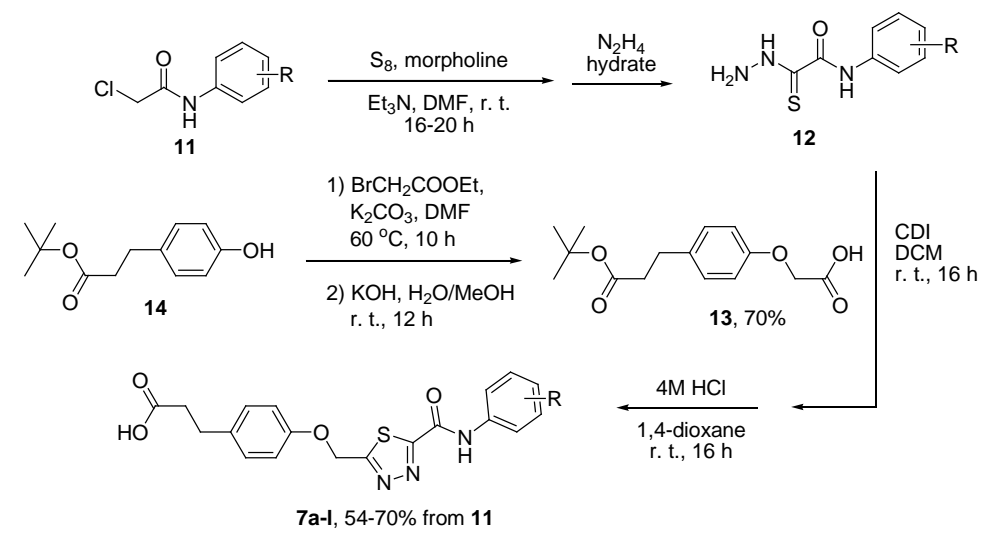

Both sets of potential GPR40 agonists (6a-e and 7a-l) were tested for FFA1 activation using a calcium flux assay conducted on Chinese hamster ovary (CHO) cells. All compounds were tested in concentration-response (\% GPR40 activation) mode in order to determine EC50 values, which are presented in Table 1.

Table 1. Structures, cGhemical yields -and GPR40 activationactivitites data-and lipophilicities of agonists 6a-e and $7 \mathbf{a}-\mathbf{l}$.

\begin{tabular}{|c|c|c|c|c|}
\hline Compound & $\mathrm{R}$ & Isolated yield (\%) & $\mathrm{GPR}^{2} \mathrm{EC}_{50} \pm \mathrm{SD}, \mu \mathrm{M}^{*}$ & $\operatorname{cLog}^{16}$ \\
\hline $6 \mathbf{6 a}$ & $3-\left(3-\mathrm{MeC}_{6} \mathrm{H}_{4}\right)$ & 82 & $0.76 \pm 0.08$ & $3.87 \pm 0.64$ \\
\hline 6b & $3-\left(3-\mathrm{ClC}_{6} \mathrm{H}_{4}\right)$ & 80 & $1.69 \pm 0.12$ & $3.98 \pm 0.65$ \\
\hline 6c & $3-\left(4-\mathrm{FC}_{6} \mathrm{H}_{4}\right)$ & 78 & $1.28 \pm 0.15$ & $3.35 \pm 0.69$ \\
\hline 6d & 3-(2-furyl) & 64 & $1.64 \pm 0.12$ & $2.72 \pm 0.65$ \\
\hline 6e & $\mathrm{BnO}$ & 76 & $17.94 \pm 3.28$ & $3.08 \pm 0.65$ \\
\hline $7 a$ & $\mathrm{H}$ & 60 & $1.06 \pm 0.14$ & $2.78 \pm 0.64$ \\
\hline $7 \mathbf{b}$ & $4-\mathrm{MeO}$ & 62 & $>10.00$ & $2.73 \pm 0.64$ \\
\hline 7c & $2-\mathrm{F}$ & 58 & $0.58 \pm 0.10$ & $2.75 \pm 0.64$ \\
\hline 7d & 3-Me & 54 & $1.77 \pm 0.17$ & $3.24 \pm 0.64$ \\
\hline $7 e$ & $4-\mathrm{F}$ & 58 & $6.64 \pm 1.87$ & $3.23 \pm 0.67$ \\
\hline
\end{tabular}




\begin{tabular}{|c|c|c|c|c|}
\hline $\mathbf{7 f}$ & $2-\mathrm{Me}$ & 56 & $1.52 \pm 0.18$ & $3.24 \pm 0.64$ \\
\hline $\mathbf{7 g}$ & $4-\mathrm{Cl}$ & 63 & $3.69 \pm 0.95$ & $3.77 \pm 0.64$ \\
\hline $\mathbf{7 h}$ & $3-\mathrm{F}$ & 55 & $1.19 \pm 0.19$ & $3.27 \pm 0.67$ \\
\hline $\mathbf{7 i}$ & $3-\mathrm{MeO}$ & 62 & $4.68 \pm 0.80$ & $3.04 \pm 0.64$ \\
\hline $\mathbf{7 j}$ & $3,4-\mathrm{diF}$ & 70 & $0.58 \pm 0.09$ & $3.62 \pm 0.70$ \\
\hline $\mathbf{7 k}$ & $4-\mathrm{Me}$ & 54 & $4.30 \pm 1.56$ & $3.24 \pm 0.64$ \\
\hline $\mathbf{7 l}$ & $3-\mathrm{Cl}$ & 54 & $10.62 \pm 1.02$ & $3.81 \pm 0.65$ \\
\hline
\end{tabular}

* Each value is an average of $n=4$.

In analyzing the data on biological activity against FFA1, it should be borne in mind that the anilide periphery in the series of the receptor agonists represented by compound $\mathbf{5}$ was designed so as to impart higher lipophilicity to otherwise overly hydrophilic 3-(1,2,41,3,4-thiadiazol-2-yl)propanoic acid scaffold (vide supra) and thus increase affinity to the receptor (the physiological activation of which is triggered by endogenous fatty acid ligands like eicosatienoic acid). ${ }^{18}$ From the data obtained for a-even a small set (6a-e) of higher-logP analogs of compound 5, it becomes apparent that our hypothesis of using lipophilicity as a driver of potency against FFA1 was correct. Indeed, four out of five analogs had significantly higher potency compared to $\mathbf{5}_{2}$-(with the best compound, $\mathbf{6 a}$, leading into the submicromolar range). The lower potency of $\mathbf{6 e}$ most is likely due to conformational rigidity requirement in the portion of the molecule opposite to carboxylic acid functionality, which is present in biphenyl analogs 6a-d and is lost after introduction of the $-\mathrm{CH}_{2} \mathrm{O}$ - linker in $\mathbf{6 e}$.

The overall very satisfactory potency profile of compounds 7a-l suggests that 1,2,41,3,4-thiadiazole-2carboxamide moiety was a suitable periphery group to add to the 3-phenylpropanoic acid core in order to improve affinity to FFA1. The agonist activity in this series appears to be particularly sensitive to the substitutions in the anilide moiety, thus attesting for the importance of the latter for building efficient interactions with the receptor. Clearly, substitution in position 4 of the phenyl ring is particularly detrimental for the activity $(\mathbf{7 b}, \mathbf{7 g}, \mathbf{7 e}, \mathbf{7 k})$. Substituents in positions 2 and 3 seem to be well tolerated, with one of twothe most active compounds (7c) having fluorine in position 2. The high potency of the 3,4-difluorophenyl compound (7j) is somewhat surprising in light of the relatively low potency of the 4fluorophenyl compound (7e).

It was important to establishWe next evaluated the selectivity profile of the most potent GPR40 agonists from both series studied here $(\mathbf{6 a}, \mathbf{6 c}, \mathbf{7 c}$ and $\mathbf{7 j}$ ) against other GPCRs binding free fatty acidsfree fatty acid receptors (FFA3/GPR41, FFA2/GPR43 and FFA4/GPR120). While the four FFARs share a significant similarity, GPR41 FFA2 and GPR43-FFA3 agonists are usuallyhave a preference in binding shorter short-chain fatty acids while GPR40-FFA1 and GPR120-FFA4 have a higher affinity to medium- 
and long-chain fatty acids. ${ }^{19,20}$ As it is seen from the activation-activity data against this panel of GPRsGPCRs, the four lead compounds displayed high selectivity for GPR40-FFA1 (Table 2).

Table 2. Selectivity profile for compounds $\mathbf{6 a}, \mathbf{6 c}, \mathbf{7} \mathbf{c}$ and $\mathbf{7 j}{ }^{a}$

\begin{tabular}{|l|c|c|c|c|}
\hline$\underline{\text { ??? }}$ & $\mathbf{6 a}$ & $\mathbf{6 c}$ & $\mathbf{7 c}$ & $\mathbf{7 j}$ \\
\hline human FFA1/GPR40 EC $50(\mu \mathrm{M})$ & 0.76 & 1.28 & 0.58 & 0.58 \\
\hline human FFA3/GPR41 EC $50(\mu \mathrm{M})$ & $>10$ & $>10$ & $>10$ & $>10$ \\
\hline human FFA2/GPR43 EC $50(\mu \mathrm{M})$ & $>10$ & $>10$ & $>10$ & $>10$ \\
\hline human FFA4/GPR120 EC $50(\mu \mathrm{M})$ & $>10$ & $>10$ & $>10$ & $>10$ \\
\hline
\end{tabular}

${ }^{a}$ Each values is an average of $n=4$ in the presence of $0.1 \%$ BSA.

Figure 4. Docked poses of compounds $\mathbf{5}$ and $\mathbf{6 a}$ at FFA1.*

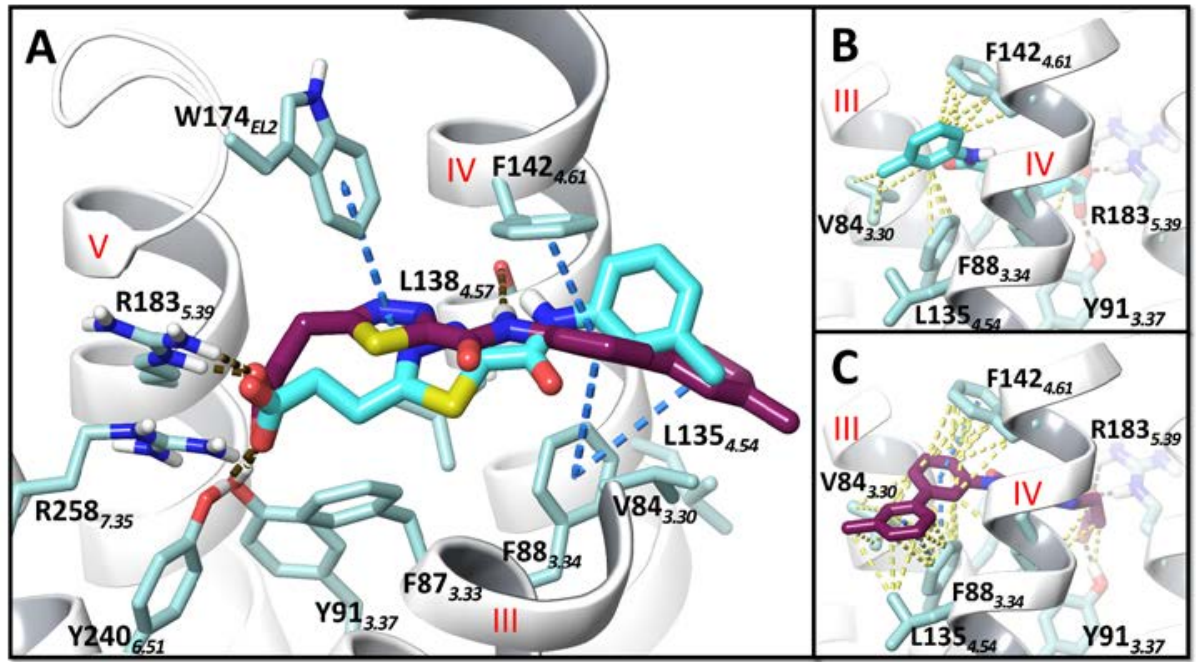

* (A) Overlay of $\mathbf{5}$ and $\mathbf{6 a}$ in the FFA1 binding site. Compounds $\mathbf{5}$ and 6a are in magenta-cyan and yellow magenta color, respectively. Protein-ligand interactions are visualized for compound 6a only. (B) Hydrophobic interactions of the terminal ring of compound 5 with FFA1. (C) Hydrophobic and $\pi$ - $\pi$ interactions of the biphenyl moiety of compound $\mathbf{6 a}$ with FFA1. Hydrogen bonds, $\pi-\pi$ and hydrophobic interactions are in a brown, blue and yellow dashed-line, respectively. Residues are labeled with their position followed by the Ballesteros and Weinstein numbering. ${ }^{21}$. Transmembrane helices are labeled in red, Roman numerals. 
To gain a structural understanding of improved potency of $\mathbf{6 a}$ compared to $\mathbf{5}$, we have docked $\mathbf{6 a}$ and $\mathbf{5}$ in the FFA1 binding site. As visualized in Figure 4A, both compounds have a similar orientation within the binding cavity forming hydrogen bonds with R1835.39, Tyr913.37, Tyr2406.51 and the backbone of L1384.57. While the more potent agonists (TAK-875, AMG 837 and LY2881835) substitute the 1,3,4thiadizole with a more hydrophobic benzene ring, thiadizole is still well accommodated within the binding site. This can be justified by its propensity to form $\pi-\pi$ interactions with W174 $\mathrm{EL} 2$ and possibly F873.33.

The phenyl ring of $\mathbf{5}$ is at the interhelical space of helices 3 and 4, forming hydrophobic interactions with V843.30, F883.34 and F1424.61 (Figure 4B). In contrast, the same phenyl ring of 6a positions deeper within the binding cavity forming $\pi-\pi$ stacking interactions with F883.34 and F1424.61 (Figure 4C). It appears that the addition of a second phenyl ring in 6a slightly pulls the molecule inside the helical bundle. This is due to involvement of the second phenyl ring in hydrophobic interactions with V843.30 and L1354.54 and the $\pi-\pi$ stacking interaction with F88 ${ }_{3.34}$. The formation of the aromatic network with the receptor could explain the 10 -fold increase in potency observed for $\mathbf{6 a}$ compared to $\mathbf{5}$.

Figure 5. Overlay of the docked pose of compound 7c (orange) with the crystal structure conformation of TAK-875 (green) in the FFA1 binding site.*

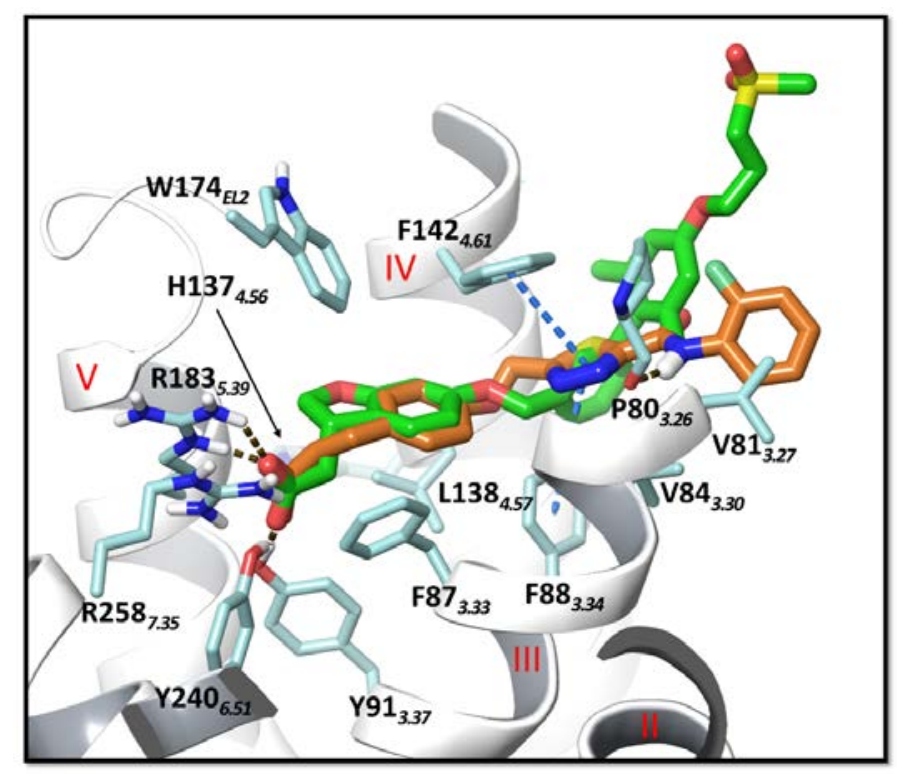

* Protein-ligand interactions are visualized for compound $\underline{7 c}$ only. Hydrogen bonds, $\pi-\pi$ and hydrophobic interactions are in a brown, blue and yellow dashed-line, respectively. Residues are labeled with their position followed by the Ballesteros and Weinstein numbering..$^{21-}$. Transmembrane helices are labeled in red, $_{2}$ Roman numerals. 
The portion of 7a-l bearing the carboxylic acid functionality is similar to the 3-[4(benzyloxy)phenyl]propanoic acid core of TAK-875. To investigate the conformational similarities between 7c (one of the most potent compounds in the series) and the TAK-875 co-crystallized with the receptor, both were docked onto FFA1 (Figure 5). Indeed, the hydrophobic benzene ring of the 3phenylpropanoic acid portion of 7c appears beneficial for agonist activity as it matches the hydrophobic environment of the active site. The position of $\mathbf{7 c}$ inside the binding cavity closely resembles that of TAK-875. However, the differences in activity is likely attributable to the variation of the agonist aromatic tail. The 2-fluorobenzene tail of 7c points straight to the lipid side, whereas in TAK-875, the 2,6-dimethylphenyl moiety of TAK-875 points toward the extracellular side of the lipids. The two methyl substituents control the dihedral angle of the biphenyl portion of TAK-875.Methyl substitutions at position 3 keeps two aromatic rings at an angle to each other. As a result, TAK-875 forms additional favorable $\pi-\pi$ stacking contacts with F1424.61. In contrast, the terminal ring of 7c connected via a rigid planar amide group extends straight and forms, similarly to 6a (vide supra), hydrophobic interactions with ${\mathrm{P} 80_{3.26}}, \mathrm{~V} 81_{3.27}$ and $\mathrm{V} 84_{3.30}$. It appears that the terminal ring of $7 \mathbf{c}$ is particularly prone to steric effects. Indeed, even moderately bulky substituents (such as those present in $\mathbf{7 b}, \mathbf{7 d}, \mathbf{7 f}, \mathbf{7 i}$ and $\mathbf{7 k}$ ) tend to lower the agonist potency.

Table 3. The in vitro ADME profile of compounds $\mathbf{6 a}, \mathbf{6 c}, \mathbf{7 c}$ and $\mathbf{7 l}$.

\begin{tabular}{|l|l|c|c|c|c|}
\hline \multicolumn{2}{|c|}{ Physicochemical properties } & $6 a$ & $6 c$ & $7 c$ & $7 \mathbf{~}$ \\
\hline \multicolumn{2}{|l|}{ Plasma stability (mouse) - T $1 / 2$, min } & $>240$ & $>240$ & 20.4 & 115.7 \\
\hline Plasma protein binding (mouse) - \% bound ${ }^{a}$ & 92.4 & 94.1 & $\mathrm{ND}^{b}$ & 92.8 \\
\hline $\begin{array}{l}\text { Metabolic stability (mouse liver } \\
\text { microsomes) }\end{array}$ & $\mathrm{T}_{1 / 2}, \mathrm{~min}$ & 77.5 & 208.9 & 6.9 & 13.2 \\
\cline { 2 - 6 } & $\mathrm{CL}_{\text {int }}, \mu \mathrm{L} / \mathrm{min} / \mathrm{mg}$ & 21.6 & 8.0 & 241.4 & 126.3 \\
\hline LogD, pH 7.4 & & 1.28 & 0.96 & 0.95 & 1.46 \\
\hline
\end{tabular}

${ }^{a}$ Each value is an average of $\mathrm{n}=2$, measured at $\mathrm{c}=1 \mu \mathrm{M}$.

${ }^{b}$ Data were inconclusive due to compound's low plasma stability.

Since we were able to reach low micromolar to sub-micromolar potency in both compound series (6 and 7), we were also keen nn $_{\text {in }}$ assessing the preliminary ADME profile ${ }_{2}$ (particularly with respect to plasma and liver microsomal stability for fof the most active compounds from these series. As it is evident from Table 3, all compounds demonstrated very favorable octanol-water distribution properties (LogD measured at $\mathrm{pH}$ 7.4) which are well within the limits of established for developable drug candidates. ${ }^{22}$ However, the metabolic and plasma stability of the two series differed significantly: compounds 6a and $\mathbf{6 c}$ displayed excellent stability (in line with our previous findings ${ }^{14}$ ) while compounds $\mathbf{7 c}$ and $\mathbf{7 l}$ were markedly unstable. This even hindered the determination of plasma protein binding for $\mathbf{7 c}$, while the other three compounds displayed a good free fraction in plasma. The latter 
unfortunate aspect (which could be related to the presence of metabolically prone 4-phenoxy-1,2,41,3,4thiadiazole linkage in 7a-I) will undoubtedly affect the prospects of developing compounds belonging to series $\mathbf{7}$ as pharmacological tools or drug candidates.

Table 4. The hERG $\underline{\mathrm{K}+\text { channel }}$ binding profile $(\% \pm \mathrm{SE})^{a}$ of compounds $\mathbf{6 a}, \mathbf{6 c}$, 7c and $\mathbf{7 l}$.

\begin{tabular}{|l|c|c|c|c|}
\hline & $\mathbf{6 a}$ & $\mathbf{6 c}$ & $\mathbf{7 c}$ & $\mathbf{7 l}$ \\
\hline $20 \mu \mathrm{M}$ & $\underline{22.0} \pm 3.6$ & $-1.0 \pm 5.7$ & $4.0 \pm 3.3$ & $\underline{36.0} \pm 6.8$ \\
\hline $5 \mu \mathrm{M}$ & $2.0 \pm 3.9$ & $-1.0 \pm 5.4$ & $-7.0 \pm 3.8$ & $-3.0 \pm 3.7$ \\
\hline $1 \mu \mathrm{M}$ & $8.0 \pm 4.5$ & $-6.0 \pm 3.3$ & $9.0 \pm 9.5$ & $1.0 \pm 8.9$ \\
\hline
\end{tabular}

${ }^{a}$ Each value is an average of $\mathrm{n}=4$.

The four lead compounds (6a, 6c, 7c, 7l) displayed wafavorable hERG binding profile as determined using Predictor ${ }^{\mathrm{TM}}$ hERG Fluorescence Polarization Assay (see Experimental section). The modest binding of two compounds (6a and 7l) can be viewed as not significant in light of the much higher potency of the compounds.

Table 5. The CYP450 inhibition profile (\% inhibition \pm SE) ${ }^{a}$ of compounds $\mathbf{6 a}, \mathbf{6 c}, \mathbf{7 c}$ and $\mathbf{7 l}$.

\begin{tabular}{|l|c|c|c|c|}
\hline$\underline{\text { CYP450 }}$ & $\mathbf{6 a}$ & $\mathbf{6 c}$ & $\mathbf{7 c}$ & 7l \\
\hline 1A2 & $94.3 \pm 0.5$ & $47.2 \pm 9.8$ & $18.8 \pm 4.5$ & $41.9 \pm 9.2$ \\
\hline 2C9 & $9.8 \pm 9.9$ & $-1.9 \pm 5.8$ & $12.8 \pm 9.7$ & $85.0 \pm 4.9$ \\
\hline 2C19 & $37.2 \pm 5.9$ & $25.2 \pm 5.4$ & $-3.3 \pm 3.6$ & $77.7 \pm 1.3$ \\
\hline 2D6 & $1.8 \pm 9.2$ & $11.8 \pm 9.4$ & $6.6 \pm 14.5$ & $22.7 \pm 1.3$ \\
\hline 3A4 & $12.3 \pm 6.3$ & $-5.1 \pm 11.1$ & $-28.7 \pm 9.6$ & $55.2 \pm 2.9$ \\
\hline
\end{tabular}

${ }^{a}$ Each value is an average of $\mathrm{n}=4$, measured at $€=\underline{\text { concentration } 20 \mu \mathrm{M}}$.

The cytochrome P450 inhibition profile assessed for five principal isoforms (1A2, 2C9, 2C19, 2D6 and $3 \mathrm{~A} 4)^{23}$ demonstrated that the occasional isoform-selective inhibition is not scaffold-related. Clearly, among two compounds in each series, compounds $\mathbf{6 c}$ and $\mathbf{7 c}$ have a markedly 'cleaner' profile and, hence, lower likelihood of causing drug-drug interactions due to CYP inhibition. ${ }^{24}$

\section{Conclusions}

We have explored two chemical series as FFA1 receptor agonists: one (6) in which 1,2,4 $\underline{1,3,4}$ thiadiazole-2-carboxamide plays the role of the core scaffold and the other (7) containing a 1,2,41,3,4thiadiazole-2-carboxamide moiety as a periphery group 'decorating' the 3-phenylpropanoic acid core (the latter is common for many known advanced FFA1 agonists). Both chemical series delivered 
compounds of sub-micromolar potency and excellent selectivity against a panel of other free fatty acid receptors (FFA2/GPR43, FFA3/GPR41 and FFA4/GPR120), confirming the correctness of the initial design idea. The observed SAR trends have also been rationalized by in silico docking of the most active compounds onto in FFA1, in comparison with the earlier described 1,2,41,3,4-thiadiazole-2carboxamide 5 and Takeda's discontinued clinical candidate TAK-875. The best compounds in each series have been profiled for ADME parameters (plasma and metabolic stability, plasma protein binding, $\operatorname{LogD}$ ( $\mathrm{pH}$ 7.4), CYP inhibition and hERG binding. Unfortunately, the low plasma and metabolic stability observed for the series 7 compounds tarnishes the series from developability perspectivefuture development. On the contraryIn contrast, series 6 displayed excellent plasma and metabolic stability, reasonable free fraction in plasma and a good CYP inhibition and hERG binding profile. Compound $\mathbf{6 c}$ clearly standsing out in terms of the overall potency and ADME profile.

\section{Experimental section}

\subsection{General experimental}

All reactions were conducted in oven-dried glassware . Melting points were measured with a Buchi B520 melting point apparatus and were not corrected. Analytical thin-layer chromatography was carried out on Silufol UV-254 silica gel plates using appropriate mixtures of ethyl acetate and hexane. Compounds were visualized with short-wavelength UV light. ${ }^{1} \mathrm{H}$ NMR and ${ }^{13} \mathrm{C}$ NMR spectra were recorded on Bruker MSL-300 spectrometers in DMSO-D6- $d_{6}$ using TMS as an internal standard. Mass spectra were recorded using Shimadzu LCMS-2020 system with electron impact (EI) ionization. All and reagents and solvents were obtained from commercial sources and used without purification.

All mass-spectroscopic measurements required for determination of ADME properties were performed using Shimadzu VP HPLC system including vacuum degasser, gradient pumps, reverse phase HPLC column, column oven and autosampler. The HPLC system was coupled with tandem mass spectrometer API 3000 (PE Sciex). The TurboIonSpray ion source was used in both positive and negative ion modes. Acquisition and analysis of the data were performed using Analyst 1.5.2 software (PE Sciex).

\subsection{Synthetic organic chemistry}

\subsubsection{Starting materials}

2-Chloroacetamides $\mathbf{8}$ and $\mathbf{1 1}$ as well as tert-butyl 3-(4-hydroxyphenyl)propionate (14) are known and commercially available compounds. 
4.2.1.1. [4-(3-Tert-butoxy-3-oxopropyl)phenoxy]acetic acid (13). A $250 \mathrm{~mL}$ round-bottomed flask was charged with a solution of tert-butyl 3-(4-hydroxyphenyl)propionate (14, $7.15 \mathrm{~g}, 32.0 \mathrm{mmol}$ ) in anhydrous DMF (50 mL). Freshly calcinated $\mathrm{K}_{2} \mathrm{CO}_{3}(3.5 \mathrm{~g}, 25.0 \mathrm{mmol})$ was added in small portions followed by a dropwise addition of a solution of ethyl bromoacetate (7.0 g, $41 \mathrm{mmol})$ in DMF (20 mL). The reaction mixture was heated, on vigorous stirring, at $60^{\circ} \mathrm{C}$ for $10 \mathrm{~h}$. The solvent was removed in vacuo and the residue was poured into water. The aqueous phase was extracted with ethyl acetate ( $3 \mathrm{x}$ $100 \mathrm{~mL}$ ). The combined organic extracts were washed with $5 \%$ aqueous $\mathrm{HCl}, 5 \%$ aqueous $\mathrm{K}_{2} \mathrm{CO}_{3}$ and brine, dried over anhydrous $\mathrm{Na}_{2} \mathrm{SO}_{4}$, filtered and concentrated in vacuo. The redisue was dissolved in methanol $(100 \mathrm{~mL})$ and a solution of $\mathrm{KOH}(2.34 \mathrm{~g})$ in water $(10 \mathrm{~mL})$ was added dropwise. The reaction mixture was stirred for $12 \mathrm{~h}$ at r. t. and the volatiles were removed in vacuo. The residue was dissolved in water $(100 \mathrm{~mL})$ and the solution was extracted with ethyl actetate $(3 \times 50 \mathrm{~mL})$ and the organic extracts were discarded. The aqueous phase was carefully acidified to $\mathrm{pH} 5$ with $5 \%$ aqueous $\mathrm{HCl}$ and extracted again with ethyl acetate $(3 \times 50 \mathrm{~mL})$. The combined organic extracts were dried over anhydrous $\mathrm{Na}_{2} \mathrm{SO}_{4}$, filtered and concentrated in vacuo. The residue was purified by column chromatography on silica gel using $0 \rightarrow 5 \%$ gradient of methanol in chloroform as eluent to provide the title compound as a white crystalline solid (6.2 g, $22.3 \mathrm{mmol}, 70 \%)$. M. p. 73-78 ${ }^{\circ} \mathrm{C}$; ${ }^{1} \mathrm{H}$ NMR (300 MHz, $\left.\mathrm{CDCl}_{3}\right) \delta 10.61(\mathrm{~s}, 1 \mathrm{H})$, 7.14 (d, $J=8.6 \mathrm{~Hz}, 1 \mathrm{H}), 6.85$ (d, $J=8.6 \mathrm{~Hz}, 2 \mathrm{H}), 4.66$ (s, 1H), 2.86 (t, $J=7.7 \mathrm{~Hz}, 1 \mathrm{H}), 2.52$ (t, $J=7.7$ $\mathrm{Hz}, 1 \mathrm{H}), 1.42$ (s, 4H); ${ }^{13} \mathrm{C}$ NMR (75 MHz, $\left.\mathrm{CDCl}_{3}\right) \delta 174.11,172.65,155.89,134.30,129.51,114.59$, 80.63, 64.94, 37.25, 30.25, 28.06; MS m/z $281.4(\mathrm{M}+\mathrm{H}+)$.

\subsubsection{General procedure for the preparation of compounds $6 a-e$}

To a suspension of elementary sulfur (512 mg, $16.0 \mathrm{mmol}$ ) in dry DMF (20 mL) was sequentially added (in dropwise fashion) triethylamine $(2.25 \mathrm{~mL}, 16.0 \mathrm{mmol})$ and morpholine $(1.06 \mathrm{mmol})$ and the resulting mixture was stirred for $30 \mathrm{~min}$. Then it was treated with a solution of respective 2-chloroacetamides 8 $(0.5 \mathrm{mmol})$. The mixture was stirred overnight, poured into water $(50 \mathrm{~mL})$ and the resulting precipitate was separated by filtration and air-dried. It was then suspended in acetone $(50 \mathrm{~mL})$ and the insoluble residue of excess of unreacted sulfur was filtered off and discarded. The filtrate was evaporated to dryness and the dry residue was dissolved in dry DMF $(15 \mathrm{~mL})$, treated with hydrazine hydrate $(2.5 \mathrm{~mL})$ and stirred for 12 hours. The reaction mixture was poured into water, the $\mathrm{pH}$ of the aqueous medium was adjusted to 5.0 with $2 \mathrm{M}$ aqueous $\mathrm{HCl}$. The resulting precipitate of $\mathbf{1 0}$ was filtered off and used in the next step without further purification (purity of at least $90 \%$ was estimated based on ${ }^{1} \mathrm{H}$ NMR analysis). Thiohydrazide $\mathbf{1 0}$ thus obtained was placed in a thick-walled crew-capped glass tube along with succinic anhydride $(1.2 \mathrm{mmol})$ and glacial acetic acid $(3.0 \mathrm{~mL})$. The reaction mixture was heated at reflux temperature on vigorous stirring over 2 hours, cooled down and poured into water $(25 \mathrm{~mL})$. 
The precipitate formed was filtered off and air dried to deliver analytically pure compounds $\mathbf{6 a - e}$ in yields indicated.

4.2.2.1. 3-\{5-[(3'-methylbiphenyl-3-yl)carbamoyl]-1,3,4-thiadiazol-2-yl\}propanoic acid (6a). Compound 6a was obtained as a white solid (150 mg, 82\%). M. p. 156-159 ${ }^{\circ} \mathrm{C}$; ${ }^{1} \mathrm{H}$ NMR $(300 \mathrm{MHz}$, DMSO-d $\left.{ }_{6}\right) \delta 12.41$ (s, $\left.1 \mathrm{H}\right), 11.17$ (s, 1H), 8.17 (s, 1H), 7.84 (dd, $\left.J=7.2,3.7 \mathrm{~Hz}, 1 \mathrm{H}\right), 7.49-7.41$ (m, 4H), 7.37 (t, $J=7.5 \mathrm{~Hz}, 1 \mathrm{H}), 7.20$ (d, $J=7.3 \mathrm{~Hz}, 1 \mathrm{H}), 3.40$ (t, $J=6.9 \mathrm{~Hz}, 2 \mathrm{H}), 2.84(\mathrm{t}, J=7.0 \mathrm{~Hz}, 2 \mathrm{H})$, 2.39 (s, 3H); ${ }^{13} \mathrm{C}$ NMR (75 MHz, DMSO- $\left.d_{6}\right) \delta 173.64,172.86,165.77,156.35,140.78,139.80,138.21$, 138.07, 129.24, 128.82, 128.24, 127.23, 123.71, 122.87, 119.61, 119.09, 32.71, 25.25, 21.06. HRMS (ESI) $\mathrm{m} / \mathrm{z}$ calcd for $\mathrm{C}_{19} \mathrm{H}_{17} \mathrm{~N}_{3} \mathrm{O}_{3} \mathrm{SNa}\left[\mathrm{M}+\mathrm{Na}^{+}\right]$390.0883, found 390.0883 .

4.2.2.2. 3-\{5-[(3'-chlorobiphenyl-3-yl)carbamoyl]-1,3,4-thiadiazol-2-yl\}propanoic acid (6b). Compound 6b was obtained as a white solid (155 mg, 80\%). M. p. 159-162 ${ }^{\circ} \mathrm{C}$; ${ }^{1} \mathrm{H}$ NMR (300 MHz, DMSO-d $_{6}$ ) $\delta 12.42$ (s, $\left.1 \mathrm{H}\right), 11.18$ (s, $\left.1 \mathrm{H}\right), 8.19$ (s, 1H), 7.91 (d, $\left.J=6.0 \mathrm{~Hz}, 1 \mathrm{H}\right), 7.69$ (s, 1H), 7.63 (d, $J$ $=7.5 \mathrm{~Hz}, 1 \mathrm{H}), 7.56-7.42(\mathrm{~m}, 5 \mathrm{H}), 3.40(\mathrm{t}, J=6.9 \mathrm{~Hz}, 2 \mathrm{H}), 2.84(\mathrm{t}, J=7.0 \mathrm{~Hz}, 2 \mathrm{H}) ;{ }^{13} \mathrm{C}$ NMR $(75 \mathrm{MHz}$, DMSO- $\left.d_{6}\right) \delta 173.79,172.99,165.79,156.43,141.98,139.08,138.40,133.81,130.88,129.54,127.53$, 126.37, 125.33, 123.03, 120.30, 119.19, 32.74, 25.31. HRMS (ESI) $\mathrm{m} / \mathrm{z}$ calcd for $\mathrm{C}_{18} \mathrm{H}_{14} \mathrm{ClN}_{3} \mathrm{O}_{3} \mathrm{SNa}$ $\left[\mathrm{M}+\mathrm{Na}^{+}\right], 410.0336$, found 410.0337 .

4.2.2.3. 3-\{5-[(4'-fluorobiphenyl-3-yl)carbamoyl]-1,3,4-thiadiazol-2-yl\}propanoic acid (6c). Compound 6c was obtained as a white solid (145 mg, 78\%). M. p. $279-181{ }^{\circ} \mathrm{C}$; ${ }^{1} \mathrm{H}$ NMR $(300 \mathrm{MHz}$, DMSO-d $\left._{6}\right) \delta 11.79$ (s, $1 \mathrm{H}$ ), 8.76 (s, $\left.1 \mathrm{H}\right), 8.46$ (dd, $J=6.5,2.2 \mathrm{~Hz}, 1 \mathrm{H}$ ), 8.30 (dd, $J=8.7,5.5 \mathrm{~Hz}, 2 \mathrm{H}$ ), $8.11-8.03$ (m, 2H), 7.93 (t, $J=8.8 \mathrm{~Hz}, 2 \mathrm{H}), 4.01(\mathrm{t}, J=6.9 \mathrm{~Hz}, 2 \mathrm{H}), 3.45(\mathrm{t}, J=6.9 \mathrm{~Hz}, 2 \mathrm{H}) ;{ }^{13} \mathrm{C} \mathrm{NMR}$ $\left(75 \mathrm{MHz}, \mathrm{DMSO}-d_{6}\right) \delta 173.78,173.00,165.82,161.99(\mathrm{~d}, J=244.63 \mathrm{~Hz}), 156.43,139.69,138.32$, 136.36 (d, $J=2.94 \mathrm{~Hz}), 129.43,128.64$ (d, $J=8.31 \mathrm{~Hz}), 122.93,119.73,119.07,115.84$ (d, $J=21.45$ $\mathrm{Hz}$ ), 32.76, 25.31. HRMS (ESI) $\mathrm{m} / \mathrm{z}$ calcd for $\mathrm{C}_{18} \mathrm{H}_{14} \mathrm{FN}_{3} \mathrm{O}_{3} \mathrm{SNa} 394.0632$, found 394.0632 .

4.2.2.4. 3-(5-\{[3-(furan-2-yl)phenyl]carbamoyl\}-1,3,4-thiadiazol-2-yl)propanoic acid (6d). Compound 6d was obtained as a white solid (110 mg, 64\%). M. p. 218-221 ${ }^{\circ} \mathrm{C}$; ${ }^{1} \mathrm{H}$ NMR (300 MHz, DMSO-d $\left.d_{6}\right) \delta 12.42$ (s, $\left.1 \mathrm{H}\right), 11.18$ (s, $1 \mathrm{H}$ ), 8.25 (s, $\left.1 \mathrm{H}\right), 7.75$ (dd, $J=12.8,4.7 \mathrm{~Hz}, 2 \mathrm{H}$ ), 7.51 (d, $J=7.8$ $\mathrm{Hz}, 1 \mathrm{H}), 7.42$ (t, $J=7.9 \mathrm{~Hz}, 1 \mathrm{H}), 6.91$ (d, $J=3.3 \mathrm{~Hz}, 1 \mathrm{H}), 6.61$ (dd, $J=3.3,1.8 \mathrm{~Hz}, 1 \mathrm{H}), 3.39$ (t, $J=7.0$ $\mathrm{Hz}, 2 \mathrm{H}), 2.83$ (t, $J=6.9 \mathrm{~Hz}, 2 \mathrm{H}) ;{ }^{13} \mathrm{C}$ NMR $\left(75 \mathrm{MHz}, \mathrm{DMSO}-d_{6}\right) \delta 173.74,172.98,165.77,156.46$, 152.69, 143.13, 138.30, 130.79, 129.38, 119.86, 119.81, 115.63, 112.14, 106.17, 32.72, 25.29. HRMS (ESI) $\mathrm{m} / \mathrm{z}$ calcd for $\mathrm{C}_{16} \mathrm{H}_{13} \mathrm{~N}_{3} \mathrm{O}_{4} \mathrm{SNa}\left[\mathrm{M}+\mathrm{Na}^{+}\right]$366.0519, found 366.0519. 
4.2.2.5. 3-(5-\{[4-(benzyloxy)phenyl]carbamoyl\}-1,3,4-thiadiazol-2-yl)propanoic acid (6e). Compound 6e was obtained as a white solid (146 mg, 76\%). M. p. 205-207 ${ }^{\circ} \mathrm{C}$; ${ }^{1} \mathrm{H}$ NMR (300 MHz, DMSO-d 6 ) $\delta 12.42$ (s, $1 \mathrm{H}), 11.00$ (s, $1 \mathrm{H}), 7.74$ (d, $J=8.6 \mathrm{~Hz}, 2 \mathrm{H}), 7.3-7.5$ (m, 5H), 7.02 (d, $J=8.6$ $\mathrm{Hz}, 2 \mathrm{H}), 5.10$ (s, 2H), 3.38 (t, $J=6.7 \mathrm{~Hz}, 2 \mathrm{H}), 2.82(\mathrm{t}, J=6.7 \mathrm{~Hz}, 2 \mathrm{H}) ;{ }^{13} \mathrm{C}$ NMR $\left(75 \mathrm{MHz}, \mathrm{DMSO}-d_{6}\right)$ $\delta 173.89,173.36,166.45,156.34,155.74,137.55,131.41,128.88,128.27,128.14,122.76,115.33$, 69.86, 33.24, 25.73. HRMS (ESI) $\mathrm{m} / \mathrm{z}$ calcd for $\mathrm{C}_{19} \mathrm{H}_{17} \mathrm{~N}_{3} \mathrm{O}_{4} \mathrm{SNa}\left[\mathrm{M}+\mathrm{Na}^{+}\right]$406.0835, found 406.0837.

\subsubsection{General procedure for the preparation of compounds 7a-l}

Compounds 7a-l were prepared in the same manner and on the same scale $(0.5 \mathrm{mmol}$ of 2chloroacetanilides 11) as described above for the preparation of compounds 6a-e, except for the 1,2,41,3,4-thiadiazole-forming step. To a solution of [4-(3-tert-butoxy-3-oxopropyl)phenoxy]acetic acid (13, $0.5 \mathrm{mmol}, 140 \mathrm{mg})$ in DCM (4 mL) carbonyldiimidazole $(0.55 \mathrm{mmol}, 90 \mathrm{mg})$ was added and the mixture was stirred at r. t. for $30 \mathrm{~min}$. To the resulting solution of the carboxylic acid imidazolide, thiohydrazide 12 (obtained in the reaction of 2-chloroacetanilide 11 with morpholine and elementary sulfur in the presence of $\mathrm{Et}_{3} \mathrm{~N}$ followed by treatment with hydrazine hydrate) was added and the reaction mixture was stirred at r. t. for $16 \mathrm{~h}$. The solvent was removed in vacuo, the residue was dissolved in glacial acetic acid $(3 \mathrm{~mL})$ and the solution was heated at reflux for $30 \mathrm{~min}$. It was then cooled down to r. t., poured into water $(50 \mathrm{~mL})$ and the resulting precipitate was collected by filtration and dried in vacuo. It was then combined with $4 \mathrm{M}$ solution of $\mathrm{HCl}$ in 1,4-dioxane $(5 \mathrm{~mL})$; the mixture was stirred at r. t. for $16 \mathrm{~h}$ and poured into water $(50 \mathrm{~mL})$. The precipitate was collected by filtration, washed with water and air-dried to provide compound $\mathbf{7 a - l}$ in yields indicated.

4.2.3.1. 3-(4-\{[5-(Phenylcarbamoyl)-1,3,4-thiadiazol-2-yl]methoxy\}phenyl)propanoic acid (7a). Compound 7a was obtained as a white solid (115 mg, 60\%). M. p. 199-206 ${ }^{\circ} \mathrm{C}$; ${ }^{1} \mathrm{H}$ NMR (300 MHz, DMSO-d $_{6}$ ) $\delta 12.13$ (s, $1 \mathrm{H}$ ), 11.20 (s, $\left.1 \mathrm{H}\right), 7.84$ (d, $J=7.9 \mathrm{~Hz}, 2 \mathrm{H}$ ), 7.38 (t, $J=7.8 \mathrm{~Hz}, 2 \mathrm{H}$ ), 7.17 (dd, $J$ = 11.5, $8.0 \mathrm{~Hz}, 3 \mathrm{H}$ ), 7.01 (d, J = 8.5 Hz, 2H), 5.64 (s, 2H), 2.77 (t, $J=7.5 \mathrm{~Hz}, 2 \mathrm{H}), 2.50$ (t, $J=7.5 \mathrm{~Hz}$, $2 \mathrm{H}) ;{ }^{13} \mathrm{C}$ NMR (75 MHz, DMSO-d $\left.d_{6}\right) \delta 173.79,171.65,166.76,156.03,155.47,137.66,134.32,129.45$, 128.79, 124.77, 120.83, 114.93, 64.31, 35.43, 29.49. HRMS (ESI) $\mathrm{m} / \mathrm{z}$ calcd for $\mathrm{C}_{19} \mathrm{H}_{17} \mathrm{~N}_{3} \mathrm{O}_{4} \mathrm{SNa}$ $\left[\mathrm{M}+\mathrm{Na}^{+}\right], 406.0832$, found 406.0832 .

4.2.3.2. 3-[4-(\{5-[(4-Methoxyphenyl)carbamoyl]-1,3,4-thiadiazol-2-yl\}methoxy)phenyl]propanoic acid (7b). Compound $7 \mathbf{b}$ was obtained as a white solid (128 mg, 62\%). M. p. 198-203 ${ }^{\circ} \mathrm{C}$; ${ }^{1} \mathrm{H}$ NMR (300 MHz, DMSO-d 6 ) $\delta 12.12$ (s, 1H), 11.09 (s, 1H), 7.76 (d, $J=7.9 \mathrm{~Hz}, 2 \mathrm{H}$ ), 7.19 (d, $J=7.4 \mathrm{~Hz}, 2 \mathrm{H}$ ), 6.98 (dd, $J=19.8,7.9 \mathrm{~Hz}, 4 \mathrm{H}), 5.63$ (s, 2H), 3.74 (s, 3H), 2.77 (t, $J=7.5 \mathrm{~Hz}, 2 \mathrm{H}), 2.50$ (t, $J=7.5 \mathrm{~Hz}, 2 \mathrm{H}$ ); ${ }^{13} \mathrm{C}$ NMR (75 MHz, DMSO- $\left.d_{6}\right) \delta 173.81,171.45,166.95,156.25,155.57,155.48,134.32,130.68$, 
129.45 122.33, 114.93, 113.90, 64.31, 55.21, 35.44, 29.50. HRMS (ESI) $m / z$ calcd for $\mathrm{C}_{20} \mathrm{H}_{19} \mathrm{~N}_{3} \mathrm{O}_{5} \mathrm{SNa}$ $\left[\mathrm{M}+\mathrm{Na}^{+}\right]$436.0937, found 436.0938 .

4.2.3.3. 3-[4-(\{5-[(2-Fluorophenyl)carbamoyl]-1,3,4-thiadiazol-2-yl\}methoxy)phenyl]propanoic acid (7c). Compound 7c was obtained as a white solid (116 mg, 58\%). M. p. 198-201 ${ }^{\circ} \mathrm{C} ;{ }^{1} \mathrm{H}$ NMR (300 MHz, DMSO-d $\left.d_{6}\right) 12.12$ (s, 1H), $10.94(\mathrm{~s}, 1 \mathrm{H}), 7.61$ (t, $\left.J=7.7 \mathrm{~Hz}, 1 \mathrm{H}\right), 7.33$ (dd, $J=8.3,3.7 \mathrm{~Hz}, 2 \mathrm{H}$ ), 7.25 (dd, $J=7.4,4.2 \mathrm{~Hz}, 1 \mathrm{H}), 7.19$ (d, $J=8.4 \mathrm{~Hz}, 2 \mathrm{H}), 7.02$ (d, $J=8.5 \mathrm{~Hz}, 2 \mathrm{H}), 5.66$ (s, 2H), 2.77 (t, $J$ $=7.5 \mathrm{~Hz}, 2 \mathrm{H}), 2.50$ (t, $J=7.5 \mathrm{~Hz}, 2 \mathrm{H}) ;{ }^{13} \mathrm{C}$ NMR $\left(75 \mathrm{MHz}, \mathrm{DMSO}-d_{6}\right) \delta 173.65,171.71,165.70,156.17$, 155.69 (d, $J=248.09 \mathrm{~Hz}), 155.40,134.30,129.36,127.80$ (d, $J=8.31 \mathrm{~Hz}), 126.95$ (d, $J=1.21 \mathrm{~Hz}$ ), 124.43 (d, $J=3.63 \mathrm{~Hz}$ ), 124.08 (d, $J=12.28 \mathrm{~Hz}$ ), 115.93 (d, $J=19.55 \mathrm{~Hz}$ ), 114.91, 64.26, 35.35, 29.43. HRMS (ESI) $\mathrm{m} / z$ calcd for $\mathrm{C}_{19} \mathrm{H}_{16} \mathrm{FN}_{3} \mathrm{O}_{4} \mathrm{SNa}\left[\mathrm{M}+\mathrm{Na}^{+}\right]$424.0737, found 424.0738.

4.2.3.4. 3-[4-(\{5-[(3-Methylphenyl)carbamoyl]-1,3,4-thiadiazol-2-yl\}methoxy)phenyl]propanoic acid (7d). Compound 7d was obtained as a white solid (107 mg, 54\%). M. p. 185-189 ${ }^{\circ} \mathrm{C}$; ${ }^{1} \mathrm{H}$ NMR (300 MHz, DMSO-d $\left.d_{6}\right) \delta 11.10$ (s, 1H), 7.69 (s, 1H), 7.62 (d, $\left.J=8.2 \mathrm{~Hz}, 1 \mathrm{H}\right), 7.25$ (t, $\left.J=7.8 \mathrm{~Hz}, 1 \mathrm{H}\right)$, 7.19 (d, $J=8.5 \mathrm{~Hz}, 2 \mathrm{H}), 7.00$ (t, $J=8.0 \mathrm{~Hz}, 3 \mathrm{H}), 5.64$ (s, 2H), 2.77 (t, $J=7.5 \mathrm{~Hz}, 2 \mathrm{H}), 2.50$ (t, $J=7.5$ $\mathrm{Hz}, 2 \mathrm{H}), 2.31$ (s, 3H); ${ }^{13} \mathrm{C}$ NMR (75 MHz, DMSO-d 6 ) $\delta 173.65,171.48,166.69,155.90,155.43,137.92$, 137.48, 134.28, 129.35, 128.51, 125.39, 121.27, 117.99, 114.89, 64.28, 35.35, 29.43, 21.12. HRMS (ESI) $\mathrm{m} / \mathrm{z}$ calcd for $\mathrm{C}_{20} \mathrm{H}_{19} \mathrm{~N}_{3} \mathrm{O}_{4} \mathrm{SNa}\left[\mathrm{M}+\mathrm{Na}^{+}\right]$420.0988, found 420.0988 .

\subsubsection{3-[4-(\{5-[(4-Fluorophenyl)carbamoyl]-1,3,4-thiadiazol-2-yl\}methoxy)phenyl]propanoic} acid (7e). Compound 7e was obtained as a white solid (116 mg, 58\%). M. p. 192-197 ${ }^{\circ} \mathrm{C}$; ${ }^{1} \mathrm{H}$ NMR (300 MHz, DMSO- $\left.d_{6}\right) \delta 12.12$ (s, 1H), $11.28(\mathrm{~s}, 1 \mathrm{H}), 7.87$ (dd, $\left.J=9.0,5.0 \mathrm{~Hz}, 2 \mathrm{H}\right), 7.29-7.14(\mathrm{~m}, 4 \mathrm{H}), 7.01$ (d, $J=8.5 \mathrm{~Hz}, 2 \mathrm{H}$ ), 5.64 (s, 2H), 3.56 (s, 3H), 2.77 (t, $J=7.5 \mathrm{~Hz}, 2 \mathrm{H}), 2.50$ (t, $J=7.4 \mathrm{~Hz}, 2 \mathrm{H}$ ); ${ }^{13} \mathrm{C}$ NMR $\left(75 \mathrm{MHz}, \mathrm{DMSO}-d_{6}\right) \delta 173.65,171.57,166.54,158.84(\mathrm{~d}, J=241.69 \mathrm{~Hz}), 155.92,155.42,134.29$, 133.96 (d, $J=2.59 \mathrm{~Hz}), 129.35,122.72$ (d, $J=8.13 \mathrm{~Hz}$ ), 115.36 (d, $J=22.49 \mathrm{~Hz}), 114.90,64.28,35.35$, 29.43. HRMS (ESI) $\mathrm{m} / \mathrm{z}$ calcd for $\mathrm{C}_{19} \mathrm{H}_{16} \mathrm{FN}_{3} \mathrm{O}_{4} \mathrm{SNa}\left[\mathrm{M}+\mathrm{Na}^{+}\right]$424.0737, found 424.0738

4.2.3.6. 3-[4-(\{5-[(2-methylphenyl)carbamoyl]-1,3,4-thiadiazol-2-yl\}methoxy)phenyl]propanoic acid (7f). Compounds $7 \mathbf{f}$ was obtained as a white solid (111 mg, 56\%). M. p. 188-192 ${ }^{\circ} \mathrm{C}$; ${ }^{1} \mathrm{H}$ NMR (300 MHz, DMSO-d 6 ) $\delta 12.12$ (s, 1H), 10.71 (s, 1H), 7.42 - 7.36 (m, 1H), 7.31 - 7.25 (m, 1H), 7.25 - 7.21 (m, 2H), 7.19 (d, $J=8.5 \mathrm{~Hz}, 2 \mathrm{H}), 7.01$ (d, $J=8.6 \mathrm{~Hz}, 2 \mathrm{H}), 5.65$ (s, 2H), 2.77 (t, $J=7.5 \mathrm{~Hz}, 2 \mathrm{H}$ ), 2.50 (t, $J=7.5 \mathrm{~Hz}, 2 \mathrm{H}), 2.25$ (s, 3H); ${ }^{13} \mathrm{C}$ NMR (75 MHz, DMSO-d 6 ) $\delta 173.78,171.57,166.45,156.15$, 155.45, 134.85, 134.31, 133.59, 130.46, 129.45, 126.69, 126.36, 126.16, 114.92, 64.24, 35.42, 29.48, 17.76. HRMS (ESI) $\mathrm{m} / \mathrm{z}$ calcd for $\mathrm{C}_{20} \mathrm{H}_{19} \mathrm{~N}_{3} \mathrm{O}_{4} \mathrm{SNa}\left[\mathrm{M}+\mathrm{Na}^{+}\right]$420.0988, found 420.0988 . 
4.2.3.7. 3-[4-(\{5-[(4-chlorophenyl)carbamoyl]-1,3,4-thiadiazol-2-yl\}methoxy)phenyl]propanoic acid (7g). Compound $7 \mathbf{g}$ was obtained as a white solid (131 mg, 63\%). M. p. 220-222 ${ }^{\circ} \mathrm{C}$; ${ }^{1} \mathrm{H}$ NMR (300 MHz, DMSO- $d_{6}$ ) $\delta 12.12$ (s, 1H), 11.35 (s, $1 \mathrm{H}$ ), 7.88 (d, $J=8.9 \mathrm{~Hz}, 2 \mathrm{H}$ ), 7.44 (d, $J=8.8 \mathrm{~Hz}, 2 \mathrm{H}$ ), 7.19 (d, $J=8.5 \mathrm{~Hz}, 2 \mathrm{H}), 7.01$ (d, $J=8.6 \mathrm{~Hz}, 2 \mathrm{H}), 5.64$ (s, 2H), 2.77 (t, $J=7.5 \mathrm{~Hz}, 2 \mathrm{H}), 2.50$ (t, $J=7.5 \mathrm{~Hz}$, 2H); ${ }^{13} \mathrm{C}$ NMR (75 MHz, DMSO-d $\left.d_{6}\right) \delta 173.78,171.77,165.60,156.14,155.45,136.67,134.33,129.44$, 128.72, 128.48, 122.36, 114.92, 64.31, 35.44, 29.49. HRMS (ESI) $\mathrm{m} / \mathrm{z}$ calcd for $\mathrm{C}_{19} \mathrm{H}_{16} \mathrm{ClN}_{3} \mathrm{O}_{4} \mathrm{SNa}$ $\left[\mathrm{M}+\mathrm{Na}^{+}\right]$440.0442, found 440.0442 .

4.2.3.8. 3-[4-(\{5-[(3-fluorophenyl)carbamoyl]-1,3,4-thiadiazol-2-yl\}methoxy)phenyl]propanoic acid (7h). Compound $7 \mathbf{h}$ was obtained as a white solid (110 mg, 55\%). M. p. 177-181 ${ }^{\circ} \mathrm{C}$; ${ }^{1} \mathrm{H}$ NMR (300 MHz, DMSO-d $\left.d_{6}\right) \delta 12.12$ (s, 1H), 11.40 (s, 1H), $7.81-7.66$ (m, 2H), 7.41 (dd, $J=15.2,8.1 \mathrm{~Hz}, 1 \mathrm{H}$ ), 7.19 (d, $J=8.6 \mathrm{~Hz}, 2 \mathrm{H}), 7.07-6.94$ (m, 3H), 5.65 (s, 2H), 2.77 (t, $J=7.5 \mathrm{~Hz}, 2 \mathrm{H}), 2.50$ (t, $J=7.5 \mathrm{~Hz}$, 2H); ${ }^{13} \mathrm{C}$ NMR (75 MHz, DMSO-d 6 ) $\delta 173.67,171.77,166.33,161.92(\mathrm{~d}, J=241.69 \mathrm{~Hz}), 156.24$, 155.43, 139.33 (d, $J=10.90 \mathrm{~Hz}), 134.31,130.38$ (d, $J=9.34 \mathrm{~Hz}), 129.36,116.55$ (d, $J=2.77 \mathrm{~Hz}$ ), 114.91, 111.22 (d, $J=21.10 \mathrm{~Hz}$ ), 107.56 (d, $J=26.29 \mathrm{~Hz}$ ), 64.31, 35.36, 29.45. HRMS (ESI) $\mathrm{m} / \mathrm{z}$ calcd for $\mathrm{C}_{19} \mathrm{H}_{16} \mathrm{FN}_{3} \mathrm{O}_{4} \mathrm{SNa}\left[\mathrm{M}+\mathrm{Na}^{+}\right]$424.0737, found 424.0738.

4.2.3.9. 3-[4-(\{5-[(3-methoxyphenyl)carbamoyl]-1,3,4-thiadiazol-2-yl\}methoxy)phenyl]propanoic acid (7i). Compound $7 \mathbf{i}$ was obtained as a white solid (128 mg, 62\%). M. p. 156-160 ${ }^{\circ} \mathrm{C} ;{ }^{1} \mathrm{H}$ NMR (300 MHz, DMSO-d $\left._{6}\right) 12.14$ (s, 1H), 11.15 (s, 1H), 7.52 (s, 1H), 7.46 (d, $J=7.9 \mathrm{~Hz}, 1 \mathrm{H}$ ), 7.27 (t, $J=8.1$ Hz, 1H), 7.19 (d, $J=8.3 \mathrm{~Hz}, 1 \mathrm{H}), 7.01$ (d, $J=8.3 \mathrm{~Hz}, 2 \mathrm{H}), 6.75$ (d, $J=7.9 \mathrm{~Hz}, 1 \mathrm{H}), 5.64$ (s, 2H), 3.75 (s, 3H), 2.77 (t, $J=7.3 \mathrm{~Hz}, 2 \mathrm{H}), 2.50$ (t, $J=7.2 \mathrm{~Hz}, 2 \mathrm{H}) ;{ }^{13} \mathrm{C}$ NMR (75 MHz, DMSO-d 6 ) $\delta 173.67$, 171.57, 166.65, 159.40, 155.97, 155.44, 138.75, 134.30, 129.51, 129.36, 114.91, 112.94, 110.19, 106.59, 64.30, 55.02, 35.37, 29.45. HRMS (ESI) $\mathrm{m} / \mathrm{z}$ calcd for $\mathrm{C}_{20} \mathrm{H}_{19} \mathrm{~N}_{3} \mathrm{O}_{5} \mathrm{SNa}\left[\mathrm{M}+\mathrm{Na}^{+}\right]$436.0937, found 436.0938 .

4.2.3.10. 3-[4-(\{5-[(3,4-difluorophenyl)carbamoyl]-1,3,4-thiadiazol-2-yl\}methoxy)phenyl]propanoic acid (7j). Compound $7 \mathbf{j}$ was obtained as a white solid (147 mg, 70\%). M. p. 208-213 ${ }^{\circ} \mathrm{C}$; ${ }^{1} \mathrm{H}$ NMR (300 MHz, DMSO-d $\left.d_{6}\right) 12.12$ (s, 1H), 11.44 (s, 1H), 7.95 (ddd, $J=12.9,7.4,2.3 \mathrm{~Hz}, 1 \mathrm{H}$ ), $7.73-7.62$ (m, 1H), 7.46 (dd, $J=19.6,9.3 \mathrm{~Hz}, 1 \mathrm{H}), 7.19$ (d, $J=8.5 \mathrm{~Hz}, 2 \mathrm{H}), 7.01$ (d, $J=8.5 \mathrm{~Hz}, 2 \mathrm{H}), 5.64$ (s, 2H), 2.77 (t, $J=7.5 \mathrm{~Hz}, 2 \mathrm{H}), 2.49(\mathrm{t}, J=7.3 \mathrm{~Hz}, 2 \mathrm{H}) ;{ }^{13} \mathrm{C}$ NMR (75 MHz, DMSO-d $\left.d_{6}\right) \delta 173.66,171.79$, 166.21, 156.17, 155.42, 148.78 (dd, $J=13.32 \mathrm{~Hz}, 243.59 \mathrm{~Hz}$ ), 146.15 (dd, $J=12.63 \mathrm{~Hz}, 243.59 \mathrm{~Hz}$ ), 134.62 (dd, $J=2.94 \mathrm{~Hz}, 9.17 \mathrm{~Hz}$ ), 134.31, 129.35, 117.45 (d, $J=17.48 \mathrm{~Hz}$ ), 117.28 (dd, $J=3.63 \mathrm{~Hz}$, $5.36 \mathrm{~Hz}$ ), 114.90, 109.88 (d, $J=21.80 \mathrm{~Hz}), 64.29$, 35.36, 29.43. HRMS (ESI) $\mathrm{m} / \mathrm{z}$ calcd for $\mathrm{C}_{19} \mathrm{H}_{15} \mathrm{~F}_{2} \mathrm{~N}_{3} \mathrm{O}_{4} \mathrm{SNa}\left[\mathrm{M}+\mathrm{Na}^{+}\right]$442.0643, found 442.0644 . 
4.2.3.11. 3-[4-(\{5-[(4-methylphenyl)carbamoyl]-1,3,4-thiadiazol-2-yl\}methoxy)phenyl]propanoic acid (7k). Compound $7 \mathbf{k}$ was obtained as a white solid (107 mg, 54\%). M. p. 185-189 ${ }^{\circ} \mathrm{C}$; ${ }^{1} \mathrm{H}$ NMR (300 MHz, DMSO- $\left.d_{6}\right) \delta 12.11(\mathrm{~s}, 1 \mathrm{H}), 11.12(\mathrm{~s}, 1 \mathrm{H}), 7.72(\mathrm{~d}, J=8.4 \mathrm{~Hz}, 2 \mathrm{H}), 7.18$ (dd, $J=8.3,3.6 \mathrm{~Hz}, 4 \mathrm{H}$ ), 7.01 (d, $J=8.5 \mathrm{~Hz}, 2 \mathrm{H}), 5.64$ (s, 2H), 2.77 (t, $J=7.5 \mathrm{~Hz}, 2 \mathrm{H}), 2.50$ (t, $J=7.5 \mathrm{~Hz}, 3 \mathrm{H}$ ), 2.26 (d, $J=12.0$ $\mathrm{Hz}, 3 \mathrm{H}) ;{ }^{13} \mathrm{C}$ NMR (75 MHz, DMSO- $\left.d_{6}\right) \delta 173.79,171.54,166.86,155.81,155.47,135.15,134.31$, 133.87, 129.44, 129.17, 120.75, 114.93, 64.30, 35.43, 29.49, 20.55. HRMS (ESI) $\mathrm{m} / \mathrm{z}$ calcd for $\mathrm{C}_{20} \mathrm{H}_{19} \mathrm{~N}_{3} \mathrm{O}_{4} \mathrm{SNa}\left[\mathrm{M}+\mathrm{Na}^{+}\right]$420.0988, found 420.0988.

4.2.3.12. 3-[4-(\{5-[(3-chlorophenyl)carbamoyl]-1,3,4-thiadiazol-2-yl\}methoxy)phenyl]propa-noic acid (7l). Compound $7 \mathbf{l}$ was obtained as a white solid (113 mg, 54\%). M. p. 171-173 ${ }^{\circ} \mathrm{C}$; ${ }^{1} \mathrm{H}$ NMR (300 MHz, DMSO-d d $_{\text {) }} \delta 12.10$ (s, 1H), 11.39 (s, 1H), 8.00 (s, 1H), 7.81 (d, $\left.J=8.2 \mathrm{~Hz}, 1 \mathrm{H}\right), 7.41$ (t, $J=8.1$ Hz, 1H), $7.25-7.15$ (m, 3H), 7.01 (d, $J=8.6 \mathrm{~Hz}, 2 \mathrm{H}), 5.65$ (s, 2H), 2.77 (t, $J=7.5 \mathrm{~Hz}, 2 \mathrm{H}), 2.50$ (t, $J$ $=7.5 \mathrm{~Hz}, 2 \mathrm{H}) ;{ }^{13} \mathrm{C}$ NMR $\left(75 \mathrm{MHz}\right.$, DMSO-d $\left.d_{6}\right) \delta 173.78,171.88,166.38,156.33,155.45,139.15,134.33$, 133.04, 130.50, 129.44, 124.49, 120.27, 119.24, 114.92, 64.30, 35.43, 29.48. HRMS (ESI) $\mathrm{m} / \mathrm{z}$ calcd for $\mathrm{C}_{19} \mathrm{H}_{16} \mathrm{ClN}_{3} \mathrm{O}_{4} \mathrm{SNa}\left[\mathrm{M}+\mathrm{Na}^{+}\right]$440.0442, found 440.0442 .

\subsection{Molecular modeling}

\subsubsection{Protein structure source and preparation for docking}

The crystal structure of FFA1 complexed with TAK-875, with PDB code: 4phu was used for docking studies. ${ }^{25}$ All in silico work pertaining to docking and protein preparation was carried out using the specified modules within Schrodinger's maestro, version 2016-1. ${ }^{26}$ To prepare FFA1 for docking, hydrogens, missing atoms and alternate residue positions were defined followed by optimization of the hydrogen bonding network by re-orienting hydroxyl and amide groups of Asn and Gln and identifying an appropriate orientation of the imidazole ring of His residues using Protein Preparation Wizard. ${ }^{27}$

\subsubsection{Docking protocol.}

The mutant Alą88 made for thermal stability during crystallization was mutated back to Phe followed by extensive sampling for the side-chain position. Careful positioning of the phenyl group was needed as Phe88 can be considered as an import residue in stabilizing protein-ligand binding and may influence docking results substantially. The conformation was sampled using MacroModel's Conformational Search. ${ }^{28}$ To alleviate any protein strain occurring from this point mutation, while reducing deviation from the original crystal structure coordinates, a tightly controlled, two stage minimization protocol was applied, i.e. hydrogen only minimization followed by a minimization based on constraints set from the

Commented [DM9]: I don't believe it makes sense to have separate subtitle for docking protocol, as protein preparation is contained in both. 
X-ray derived B factors. Minimisation Minimization was performed using MacroModel. ${ }^{28}$ In deciding on a final position of Phe88 and ensuring a correct docking protocol was used, TAK-875 was re-docked onto the receptor and compared to the position obtained in the crystal structure, an-RMSD of $\leq 2.5 \AA$. Prior to docking, agonists were created manually in maestro, the 2D structures were then optimized to produce a low-energy 3D structure using LigPrep. ${ }^{29}$ Glide $^{30}$ was used for receptor grid generation and ligand docking. The centroid of the receptor grid was defined by using TAK-875's crystal structure conformation. Ligands were docked using the extra precision (XP) algorithm while enhancing the planarity of conjugated pi groups. The OPLS3, all-atom force-field was employed for all calculations. In labelling the protein residues of FFA1 in figure 4 and figure 5 the number in subscript represents the Ballesteros Weinstein indexing system..$^{21}$

\subsection{Biological and ADME assays}

4.4.1. Determination of agonistic activity of compounds against GPR40, GPR41, GPR43 and GPR120 receptors

CHO cells stably expressing GPCRs (CHO-GPR40 purchased from The European Collection of Cell Cultures, ECACC) were seeded (12500cells/well) into 384-well black-wall, clear-bottom microtiter plates $24 \mathrm{~h}$ prior to assay. Cells were loaded for $1 \mathrm{~h}$ with calcium assay kit and tested using fluorometric imaging plate reader (FLIPR Tetra High Throughput Cellular Screening System by Molecular Devices). Maximum change in fluorescence over base line was used to determine agonist response. A potent and selective agonist for FFA1 (GPR40) GW9508 (Selleckchem, S8014) was tested with the test compounds as a positive control. Concentration response curve data were fitted using Molecular Devices ScreenWorks ${ }^{\circledR}$ System Control Software (Molecular Devices).

For specificity screening for possible GPR41, 43 and 120 agonism, CHO cell lines stably expressing the respective receptors (also purchased from The European Collection of Cell Cultures, ECACC) were used.

\subsubsection{Determination of the distribution coefficient (LogD, pH 7.4)}

The partitioning ratio of compounds $\mathbf{6 a}, \mathbf{6 c}, \mathbf{7 c}$ and $\mathbf{7} \mathbf{l}$ and one reference compound $\left(\log \mathrm{D}_{\mathrm{pH} 7}=2.93\right)$ was determined in $n$-octanol - phosphate buffer saline (PBS) using shake-flask method which consists of equilibrating a certain amount of a solute within the biphasic system and determining the concentration in each phase using LC-MS/MS. Equilibration was carried out in Eppendorf-type polypropylene microtubes in duplicates. $5 \mu \mathrm{L}$ aliquots of $10 \mathrm{mM}$ DMSO stock solution were added to a manually preequilibrated mixture of PBS (500 $\mu \mathrm{L})$ and $n$-octanol $(500 \mu \mathrm{L})$ and the resulting mixture was shaken for $1 \mathrm{~h}$ at $30 \mathrm{rpm}$. Phase separation was achieved by centrifugation for 2 min at $6000 \mathrm{rpm}$. The $n$-octanol 
phase was diluted 100 -fold with $40 \%$ aqueous acetonitrile and the PBS phase was diluted 10-fold with $5 \%$ aqueous acetonitrile. The partitioning ratio (D) was calculated using the formula:

$$
D=\frac{100 \cdot S_{O}}{1 \cdot S_{P}}
$$

where $S_{0}$ - peak area of the analyte in the $n$-octanol phase, $S_{p}$ - peak area of the analyte in PBS phase.

\subsubsection{Assessment of metabolic stability in mouse liver microsomes}

The metabolic stability of compound $\mathbf{6 a}, \mathbf{6 c}, \mathbf{7 c}$ and $\mathbf{7 l}$ as well as the reference compound (Propranolol) was measured in liver microsomes at five time points over 40 minutes using HPLC-MS. Metabolic stability is defined as the percentage loss of parent compound_lost-over time in the presence of a metabolically active test system, such as rodent liver microsomal fractions.

Mouse hepatic microsomes were isolated from pooled (50), perfused livers of BALB/c male mice according to the standard protocol. ${ }^{31}$-The batch of microsomes was tested for quality control using a commercial comparator preparation (Sigma-Aldrich M9441) and verapamil as reference compound. Microsomal incubations were carried out in 96-well plates in 5 aliquots of $40 \mu \mathrm{L}$ each (one for each time point). Liver microsomal incubation medium contained potassium phosphate buffer (100 mM, pH 7.4), MgCl2 (3.3 mM), NADPH (3 mM), glucose-6-phosphate (5.3 mM), glucose-6-phosphate dehydrogenase $(0.67$ units $/ \mathrm{ml})$ with $0.42 \mathrm{mg}$ of liver microsomal protein per ml. In addition, control incubations were performed replacing the NADPH-regenerating system with $100 \mathrm{mM}$ phosphate buffer $\mathrm{pH}$ 7.4. Test compounds ( $2 \mu \mathrm{M}$, final solvent concentration $1.6 \%$ ) were incubated at $37^{\circ} \mathrm{C}$ under vortexing at $100 \mathrm{rpm}$. Five time points over 40 minutes had been analyzed. The reactions were stopped by adding 12 volumes of $90 \%$ acetonitrile-water to $40 \mu \mathrm{L}$ incubation aliquots, followed by plasma protein precipitation by centrifuging at $5500 \mathrm{rpm}$ for 3 minutes. Incubations were performed in duplicates. Supernatants were analyzed using the HPLC system coupled with tandem mass spectrometer. The elimination constant $\left(\mathrm{k}_{\mathrm{el}}\right)$, half-life $\left(\mathrm{T}_{1 / 2}\right)$ and intrinsic clearance $\left(\mathrm{Cl}_{\mathrm{int}}\right)$ were determined in plot of $\ln$ (AUC) versus time, using linear regression analysis:

$$
\begin{gathered}
\mathrm{k}_{\mathrm{el}}=- \text { slope } \\
\mathrm{T}_{1 / 2}=0.693 / \mathrm{k}_{\mathrm{el}} \\
\mathrm{CL}_{\text {int }}=\left(0.693 / \mathrm{T}_{1 / 2}\right) \times(\mu \text { incubation } / \mathrm{mg} \text { microsomes })
\end{gathered}
$$

\subsubsection{Analysis of mouse plasma protein binding}

The binding of compound $\mathbf{6 a}, \mathbf{6 c}, \mathbf{7 c}$ and $\mathbf{7 l}$ as well as the reference compound (Verapamil) to mouse plasma proteins was evaluated using HPLC-MS/MS. The task was performed by spiking test compounds 
at concentration of $1 \mu \mathrm{M}$ into mice plasma (Lampire Biological Labs, US, catalog number 7304309) and dialyzing against buffer until equilibrium is achieved. Concentrations of the compounds in both plasma and buffer were determined to calculate the percentage of plasma protein bound compounds.

The assay was performed in the 96-well equilibrium dialysis apparatus (HTDialysis, LLC). Each individual well unit consisted of 2 chambers separated by a vertically aligned dialysis membrane of predetermined pore size (MWCO 12-14 kDa). $120 \mu$ of plasma spiked with the compound ( $1 \mu \mathrm{M}$, final solvent concentration 1\%) was added to one chamber and the same aliquot of PBS buffer, $\mathrm{pH} 7.4$ was added to the other chamber. After that, HTD96b dialyzer was covered with adhesive sealing film and incubated at $37^{\circ} \mathrm{C}$ on an orbital shaker at $100 \mathrm{rpm}$ for 5 hours. An aliquot of the content of each chamber had been taken and mixed with the same volume aliquot of the blank opposite matrix. In order to define non-specific loss of the compound during this assay, standard solution was created by mixing an aliquot of spiked plasma, which was incubated at $37^{\circ} \mathrm{C}$ without dialysis, with blank buffer. Sample of $1 \mu \mathrm{M}$ series was diluted with $100 \%$ acetonitrile 10 -fold with subsequent plasma proteins precipitation by centrifuging at $6000 \mathrm{rpm}$ for 5 minutes. Incubations were performed in quadriplicates. Supernatants were analyzed using HPLC system coupled with tandem mass spectrometer. The unbound compound fraction is calculated as the peak ratio of the analyte in the buffer compartment divided by the same parameter in the corresponding plasma compartment.

The following equation was used to determine the extent of plasma protein binding:

$$
\begin{gathered}
\text { protein_binding }=\left(1-\frac{\text { peak_area_in_dialysate_buffer }}{\text { peak_area_in_dialysate_plasma }}\right) \cdot 100 \% \\
\operatorname{Recov} e r y=\left(\frac{\text { peak_area_in_dialysate_buffer }+ \text { peak_area_in_dialysate_plasma }}{p e a k_{-} a r e a+i n_{-} s \tan \text { dart }_{-} \text {solution }}\right) \cdot 100 \%
\end{gathered}
$$

\subsubsection{Analysis of stability in mouse plasma}

Five $40 \mu \mathrm{L}$ aliquots of $1 \mu \mathrm{M}$ solution (final DMSO concentration 1\%) of each of the compounds (6a, 6c, 7c, 7l and two reference compounds - verapamil and propantheline) were incubated with mouse plasma (Lampire Biological Labs, US, catalog number 7304309) at $37^{\circ} \mathrm{C}$ with shaking at $100 \mathrm{rpm}$. Five time points over $120 \mathrm{~min}$ were analyzed. The reactions were stopped by the addition of acetonitrile (200 $\mu \mathrm{L}$ ) and the plasma proteins were sedimented by 5 min centrifugation at $5500 \mathrm{rpm}$. Supernatants were analyzed by LC-MS/MS. The percentage of the test compounds remaining after incubation in plasma and their half-lives $\left(\mathrm{T}_{1 / 2}\right)$ were determined. 


\subsubsection{CYP450 inhibition}

The inhibition of major CYP450 isoforms (1A2, 2C9, 2C19, 2D6, 3A4) by compounds 6a, 6c, 7c and $7 \mathbf{I}$ at a $20 \mu \mathrm{M}$ concentration was evaluated using P450-Glo ${ }^{\mathrm{TM}}$ Assay Systems (Promega) in accordance with the manufacturer's protocols. A conventional cytochrome P450 reaction was performed by incubating the cytochrome P450 and a luminogenic cytochrome P450 substrate. All test points were performed in quadruplicates. Control membranes (without CYPs) represent the Negative control (baseline). DMSO final concentration was $0.25 \%$. The following reference compounds were used to assess CYP inhibition:

\begin{tabular}{|c|c|c|c|}
\hline CYP & Reference inhibitor & Concentration , $\mu \mathrm{M}$ & $\%$ inhibition \\
\hline 1A2 & $\alpha$-Naphthoflavone & 4 & 99.21 \\
\hline 2C9 & Fluconazole & 120 & 89.09 \\
\hline 2C19 & Omeprazole & 24 & 93.40 \\
\hline 2D6 & Quinidine & 1 & 96.25 \\
\hline 3A4 & Ketoconazole & 20 & 95.37 \\
\hline
\end{tabular}

Concentrations of alfa-naphthoflavone, quinidine, ketoconazole, fluconazole and omeprazole are shown as $4 \mathrm{x}$ of Promega protocol recommendations or $4 \mathrm{x}$ of their $\mathrm{IC}_{50}$ found in the literature. ${ }^{32-33}$

\subsection{7. hERG binding}

Assessment of compounds' binding to hERG (human Ether-a-go-go-Related Gene) channel was performed using Predictor ${ }^{\mathrm{TM}}$ hERG Fluorescence Polarization Assay kit (Invitrogen, US, catalog number PV5365) according to manufacturer's protocol. The hERG reaction was performed by incubating the tracer (a small fluorescent molecule) and cell membranes containing hERG channel with the solutions of the test compounds ( $1 \mu \mathrm{M}, 5 \mu \mathrm{M}, 20 \mu \mathrm{M})$ for 4 hours. The difference of fluorescence polarization from the maximal value (no compound) was used as a measure of compound's binding to hERG channel. A strong hERG binder (compound E-4031 provided as a part of the test kit) was used as a positive control (it's reported IC $_{50}$ value is $70 \mathrm{nM}$ was confirmed experimentally prior to carrying out the testing). All measurement were performed in quandruplicates.

\section{Acknowledgements}

This research was supported by the Russian Scientific Fund (project grant 14-50-00069). We are grateful to the Center for Chemical Analysis and Materials Research of Saint-Petersburg State University for providing high-resolution mass-spectrometry data.

\section{Supplementary data}


Supplementary data associated with this article can be found, in the online version, at http://dx.doi.org/xxx.

\section{References and notes}

1. Briscoe, C. P.; Tadayyon, M.; Andrews, J. L.; Benson, W. G.; Chambers, J. K.; Eilert, M. M.; Ellis, C.; Elshourbagy, N. A.; Goetz, A. S.; Minnick, D. T.; Murdock, P. R.; Sauls, H. R.; Shabon, U.; Spinage, L. D.; Strum, J. C.; Szekeres, P. G.; Tan, K. B.; Way, J. M.; Ignar, D. M.; Wilson, S.; Muir, A. I. J. Biol. Chem. 2003, 278, 11303-11311.

2. Itoh, Y.; Kawamata, Y.; Harada, M.; Kobayashi, M.; Fujii, R.; Fukusumi, S.; Ogi, K.; Hosoya, M.; Tanaka, Y.; Uejima, H.; Tanaka, H.; Maruyama, M.; Satoh, R.; Okubo, S.; Kizawa, H.; Komatsu, H.; Matsumura, F.; Noguchi, Y.; Shinohara, T.; Hinuma, S.; Fujisawa, Y.; Fujino, M. Nature 2003, 422, 173-176.

3. Watterson, K. R.; Hudson, B. D.; Ulven, T.; Milligan, G. Front. Endocrinol. 2014, 5, 137.

4. Defossa, E.; Wagner, M. Bioorg. Med. Chem. Lett. 2014, 24, 2991-3000.

5. https://clinicaltrials.gov, last accessed on March 7, 2016.

6. Kaku, K.; Enya, K.; Nakaya, R.; Ohira, T.; Matsuno, R. Diabetes Obes. Metab. 2015, 17, 675-681.

7. Mancini, A. D.; Poitout, V. Diabetes Obes. Metab. 2015, 17, 622-629.

8. Lin, D. C.-H.; Zhang, J.; Zhuang, R.; Li, F.; Nguyen, K.; Chen, M.; TRan, T.; Lopez, E.; Lu, J. Y. L.; Li, X. N.; Tang, L.; Tonn, G. R.; Swaminath, G.; Reagan, J. D.; Chen, J.-L.; Tian, H.; Lin, Y.-J.; Houze, J. B.; Luo, J. PlosOne 2011, 6, e27270.

9. Zahanich, I.; Kondratov, I.; Naumchyk, V.; Kheylik, Y.; Platonov, M.; Zozulya, S.; Krasavin, M. Bioorg. Med. Chem. Lett. 2015, 25, 3105-3111.

10. Maekawa, T.; Hara, R.; Odaka, H.; Fukatsu, K.; Mizufune, H. PCT Int. Appl. WO 2003099793A1; Chem. Abstr. 2003, 140, 951003.

11. Hamamura, K.; Sasaki, S.; Amano, Y.; Sakamoto, J.; Fukatsu, K. PCT Int. Appl. WO 2004022551A1; Chem. Abstr. 2004, 140, 220326.

12. Yasuma, T.; Negoro, N.; Sasaki, S. PCT Int. Appl. WO 2005087710 A1; Chem. Abstr. 2005, 143, 1021733.

13. Rharma, R.; Akerman, M.; Cardozo, M. G.; Houze, J.; Li, A.-R.; Liu, J.; Liu, J.; Ma, Z.; Medina, J.C.; Schmitt, M. J.; Sun, Y.; Wang, Y.; Wang, Z.; Zhu, L. PCT Int. Appl. WO 2007106469 A2; Chem. Abstr. 2007, 147, 1064386.

14. Krasavin, M.; Lukin, A.; Zhurilo, N.; Kovalenko, A.; Zahanich, I.; Zozulya, S. J. Enzyme Inhib. Med. Chem. 2016, DOI: 10.3109/14756366.2016.1142984. 
15. Negoro, N.; Sasaki, S.; Mikami, S.; Ito, M.; Suzuki, M.; Tsujihata, Y.; Ito, R.; Harada, A.; Takeuchi, K.; Suzuki, N.; Miyazaki, J.; Santou, T.; Odani, T.; Kanzaki, N.; Funami, M.; Tanaka, T.; Kogame, A.; Matsunaga, S.; Yasuma, T.; Momose, Y. ACS Med. Chem. Lett. 2010, 1, 290-294.

16. Calculations were performed using ACD/Labs 6.00 software.

17. Yarovenko, V. N.; Shirokov, A. V.; Krupinova, O. N.; Zavarzin, I. V.; Krayushkin M. M. Russ. J. Org. Chem. 2003, 39, 1133-1139.

18. Ichimura, A.; Hirasawa, A.; Hara, T.; Tsujimoto, G. Prostaglandins Other Lipid Mediat. 2009, 89, 82-88.

19. Brown, J. A.; Goldsworthy, S. M.; Barnes, A. A.; Ellert, M. M.; Tcheang, L.; Daniels, D.; Muir, A. I.; Wogglesworth, M. J.; Kinghorn, I.; Fraser, N. J.; Pike, N. B.; Sturn, J. C.; Steplewski, K. M; Murdoch, P. R.; Holder, J. C.; Marshall, F. H.; Szekeres, P. G.; Wilson, S.; Ignar, D. M.; Foord, M. S.; Wise, A.; Dowell, S. J. J. Biol. Chem. 2003, 278, 11312-11319.

20. Hirasawa, A.; Tsumaya, K.; Awaji, T.; Katsuma, S.; Adachi, T.; Yamada, M.; Sugimoto, Y.; Miyazaki, S.; Tsujimoto, G. Nat. Med. 2005, 11, 90-94.

21. Ballesteros, J.; Weinstein, H. Biophys. J. 1995, 68, A446.

22. Ritchie, T. J.; Macdonald, S. J. F. Drug Discov. Today 2009, 14, 1011-1020.

23. Yoshimoto, K.; Echizen, H.; Chiba, K.; Tani, M.; Ishizaki, T. Br. J. Clin. Pharmacol. 1995, 39, 421431.

24. Braenden, G.; Sjoegren, T.; Schnecke, V.; Xue, Y. Drug Discov. Today 2014, 19, 905-911.

25. Srivastava, A.; Yano, J.; Hirozane, Y.; Kefala, G.; Gruswitz, F.; Snell, G.; Lane, W.; Ivetac, A.; Aertgeerts, K.; Nguyen, J.; Jennings, A.; Okada, K. Nature 2014, 513, 124-129.

26. Schrödinger, Maestro version 10.5, LLC, New York, NY, 2016.

27. Sastry, G. M.; Adzhigirey, M.; Day, T.; Annabhimoju, R.; Sherman, W. J. Comput. Aid. Mol. Des. 2013, 27, 221-234.

28. Schrödinger, Macromodel version 11.1, LLC, New York, NY, 2016.

29. Schrödinger, Ligprep version 3.7, LLC, New York, NY, 2016.

30. Friesner, R. A.; Banks, J. L.; Murphy, R. B.; Halgren, T. A.; Klicic, J. J.; Mainz, D. T.; Repasky, M. P.; Knoll, E. H.; Shelley, M.; Perry, J. K.; Shaw, D. E.; Francis, P.; Shenkin, P. S. J. Med. Chem. 2004, 47, 1739-1749.

31. Hill, J. R. In Current Protocols in Pharmacology 7.8.1-7.8.11, Wiley Interscience, 2003.

32. Li, X.-Q.; Andersson, T. B.; Ahlström M.; Weidolf, L. Drug Metab. Dispos. 2004, 32, 821-827;

33. Niwa, T.; Shiraga, T.; Takagi, A. Biol. Pharm Bull. 2005, 28, 1805-1808. 